\title{
Multidimensional Approach for Tsunami Vulnerability Assessment: Framing the Territorial Impacts in Two Municipalities in Portugal
}

\author{
Alexandre Oliveira Tavares, ${ }^{1, *}$ José Leandro Barros, ${ }^{1}$ and Angela Santos ${ }^{2}$
}

\begin{abstract}
This study presents a new multidimensional methodology for tsunami vulnerability assessment that combines the morphological, structural, social, and tax component of vulnerability. This new approach can be distinguished from previous methodologies that focused primarily on the evaluation of potentially affected buildings and did not use tsunami numerical modeling. The methodology was applied to the Figueira da Foz and Vila do Bispo municipalities in Portugal. For each area, the potential tsunami-inundated areas were calculated considering the 1755 Lisbon tsunami, which is the greatest disaster caused by natural hazards that ever occurred in Portugal. Furthermore, the four components of the vulnerability were calculated to obtain a composite vulnerability index. This methodology enables us to differentiate the two areas in their vulnerability, highlighting the characteristics of the territory components. This methodology can be a starting point for the creation of a local assessment framework at the municipal scale related to tsunami risk. In addition, the methodology is an important support for the different local stakeholders.
\end{abstract}

KEY WORDS: Composite vulnerability index (CVI); multidimensional approach; municipal; Portugal; tsunami

\section{INTRODUCTION}

In recent decades, the occurrence of disasters by natural hazards has caused a significant number of fatalities, as well as millions of euros in damages. With specific regard to tsunamis, the events that occurred in 2004 in the Indian Ocean, and more recently in Japan in 2011, demonstrate the magnitude and destructive power of the manifestation of such events. ${ }^{(1-5)}$ Recent studies $^{(6-8)}$ also highlight the raise in the exposure to this natural hazard and the in-

\footnotetext{
${ }^{1}$ Earth Sciences Department, Centre for Social Studies, Universidade de Coimbra, Coimbra, Portugal.

${ }^{2}$ Centre for Geographical Studies, Institute of Geography and Spatial Planning, Universidade de Lisboa, Lisboa, Portugal.

*Address correspondence to Alexandre Oliveira Tavares, Departamento de Ciências da Terra, Rua Sílvio Lima, Polo II Universidade de Coimbra, Coimbra 3030-790, Portugal; atavares@ci.uc.pt.
}

crease in territorial vulnerability. This fact can be explained by the progress in the mobility and concentration of people, activities, and critical infrastructure in high-risk areas, ${ }^{(9)}$ which characterizes coastal regions. ${ }^{(10)}$

In Portugal, the coastal zone $(1,187 \mathrm{~km})$ possesses a set of social, economic, physical, and environmental characteristics that differentiate it from the rest of the territory and represent a significant exposure to tsunamis. Seventy-five percent of the population and $85 \%$ of the GDP is concentrated in this zone $^{(11)}$ and would be directly or concomitantly affected by a potential tsunami inundation. The process of urbanization and coastal settlement in Portugal over the last 50 years has resulted in a littoral occupation of approximately $30 \%{ }^{(11)}$ of the coastal zone, with various types of buildings and a concentration of critical infrastructure and tourism facilities, 
Table I. Vulnerability Assessment Components Used in Different Methodologies

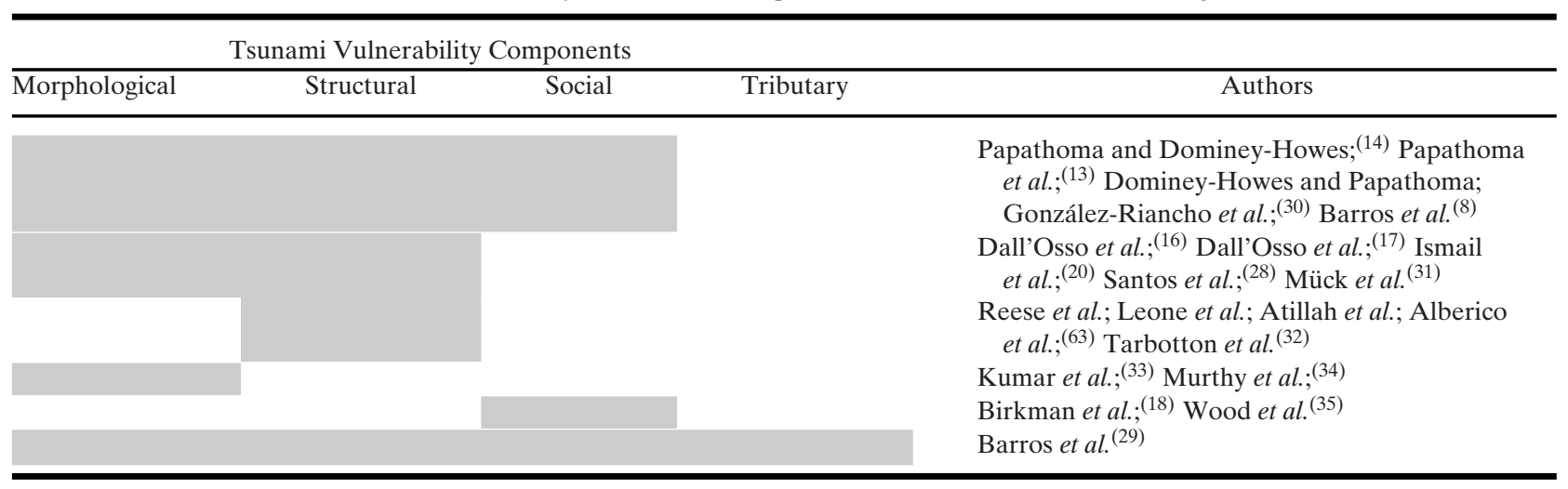

accompanied by a dense transport network. These factors significantly heighten the vulnerability and exposure of the coastal zone to the threats of extreme events, including tsunamis.

The methodological research to assess the degree of exposure and vulnerability to disasters caused by natural hazards has notably expanded in the last decade. ${ }^{(2,10,12)}$ This increase led to the emergence of a set of methodologies for risk and vulnerability assessment. With regard to the tsunamis, methodologies were produced with special emphasis on structural vulnerability. ${ }^{(2,3,13-20)}$ In Portugal, there are also several studies about the structural vulnerability of potentially affected buildings, ${ }^{(21-24)}$ with special emphasis on tsunami risk and vulnerability assessment. $^{(8,25-28)}$

Table I summarizes the existing vulnerability assessment components used in different methodological approaches. The table shows the existence of a large number of studies addressing the components of the morphological and structural vulnerability. The social dimension is being added to the vulnerability assessment in further studies. There has been a recent attempt to extend the analysis to different components, producing composite indexes such as Barros et al. ${ }^{(29)}$

However, the concept of vulnerability is dynamic and heterogeneous because it varies over the territory in accordance with a set of parameters. According to Alexander, ${ }^{(36)}$ the risk is closely related to the vulnerability and dependence of this relationship, enabling us to conclude that a particular area is at risk, and the levels of vulnerability of a population and infrastructure are at a distinct risk. This is illustrated by studies assessing the vulnerability to tsunamis, which demonstrate that the distribution is not evenly distributed along the inundation zone, depending on a multiplicity of factors. ${ }^{(13-15)}$

Complementing these findings, in this study a multidimensional vulnerability analysis is proposed for coastal areas potentially at risk of a hazardous tsunami impact, where the natural scope of the coast, existing building characteristics, social capability, and economic factors are taken into consideration. The new multidimensional approach is based on the territorial characteristics, which were grouped on four components. This was supported by previously validated methodologies. Furthermore, this innovative methodology assesses tsunami vulnerability in terms of the morphological component, ${ }^{(20-37)}$ structural component, ${ }^{(16-20)}$ social component ${ }^{(38-41)}$ and taxable property component. Portugal does not have significant earthquake activity. However, the largest earthquake occurred on November 1, 1755, with an estimated magnitude of 8.7 that triggered a tsunami. This historical event caused significant damage and fatalities, especially along the Portuguese coast. ${ }^{(42)}$ Therefore, in this study, the 1755 Lisbon tsunami will be analyzed as the worst-case scenario. ${ }^{(43,44)}$ In addition, the main features of this historical event were put together by Santos et al., ${ }^{(42)}$ which provided a reliable tsunami source model. The tsunami numerical model animation is available at: https:// sites.google.com/a/campus.ul.pt/tsurima/publications. Moreover, Santos and Koshimura ${ }^{(44)}$ calculated the detailed inundated areas at Figueira da Foz, Portugal, by using the tsunami numerical model. The animation of the output results are available at: https:// sites.google.com/a/campus.ul.pt/tsurima/publications /a-papers-1. Also, the detailed inundated areas at Vila do Bispo, Portugal, were calculated by Santos 2008. ${ }^{(43-45)}$ Thus, the inundated areas calculated by 


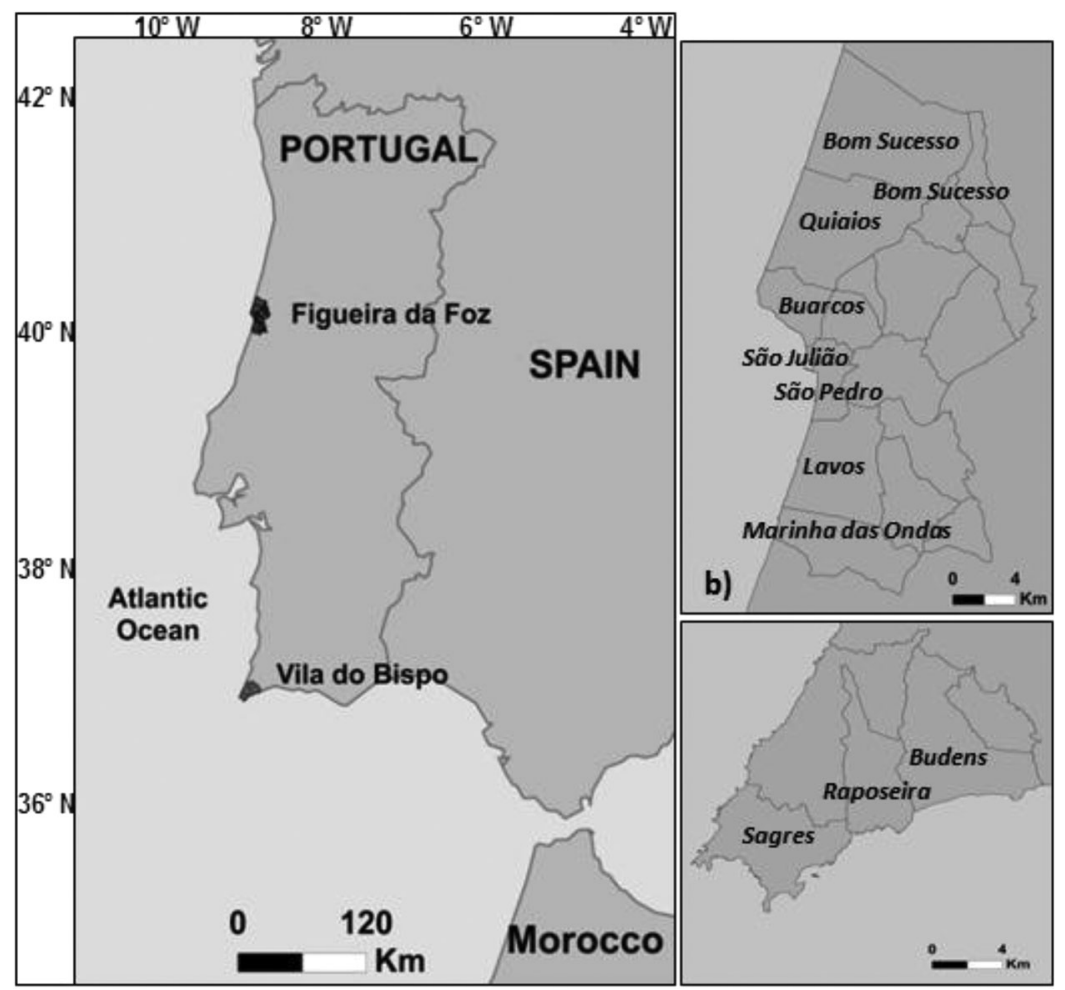

Fig. 1. Location of the two study areas: (a) framework for Portugal, (b) municipality of Figueira da Foz, (c) municipality of Vila do Bispo.

these authors will be used in this study, allowing a complete tsunami vulnerability assessment with the objective of creating a model of risk governance that promotes more resilient coastal areas.

The methodology was applied in two Portuguese coastal municipalities: Figueira da Foz, located in the central region of Portugal, and Vila do Bispo, located at the furthest southwest corner of the country.

Thus, the objectives of the present research include:

(i) An assessment of the characteristics of the areas and buildings potentially affected by the inundation model, including the social and economic characteristics of the areas and their municipal surroundings.

(ii) Building vulnerability indexes for the four domains of analysis (morphology, structural, social, and taxable properties).

(iii) A calculation and representation of a composite vulnerability index (CVI) and its classification according different levels.

(iv) A comparison of the tsunami vulnerability levels for the two studied areas and their relation with territorial components.

\section{STUDY AREA CHARACTERIZATION}

This research will be focused on two Portuguese coastal areas, based on historical accounts and territorial characteristics of the 1755 Lisbon tsunami (Fig. 1). Figueira da Foz municipality has historical accounts of the 1755 Lisbon tsunami that report unexpected high tsunami run-ups of $36 \mathrm{~m} \cdot{ }^{(42-44)}$ This area is characterized by high seasonal population dynamics $^{(46)}$ and has a major fishing port and industrial zone along the coast. Vila do Bispo, which was the first municipality hit by the 1755 tsunami, less than 20 minutes after the earthquake, ${ }^{(42,43)}$ also has an important fishing port.

Although there are many uncertainties related to the 1755 Lisbon tsunami, the tsunami numerical modeling conducted by Santos ${ }^{(43)}$ and Santos et al. ${ }^{(42)}$ on a regional scale was validated by both historical accounts and geological records. This allowed for a more comprehensive analysis of the tsunami on a local scale, and the identification of the inundated areas of Figueira da Foz ${ }^{(44)}$ and Vila do Bispo ${ }^{(43)}$ (Fig. 1), with a tsunami numerical model whose cell size is $10 \mathrm{~m}$. The model representation showed a maximum water level height of $10 \mathrm{~m}$ for Figueira da Foz and $20 \mathrm{~m}$ for Vila do Bispo, where the water level represents the maximum wave height above the sea level. 

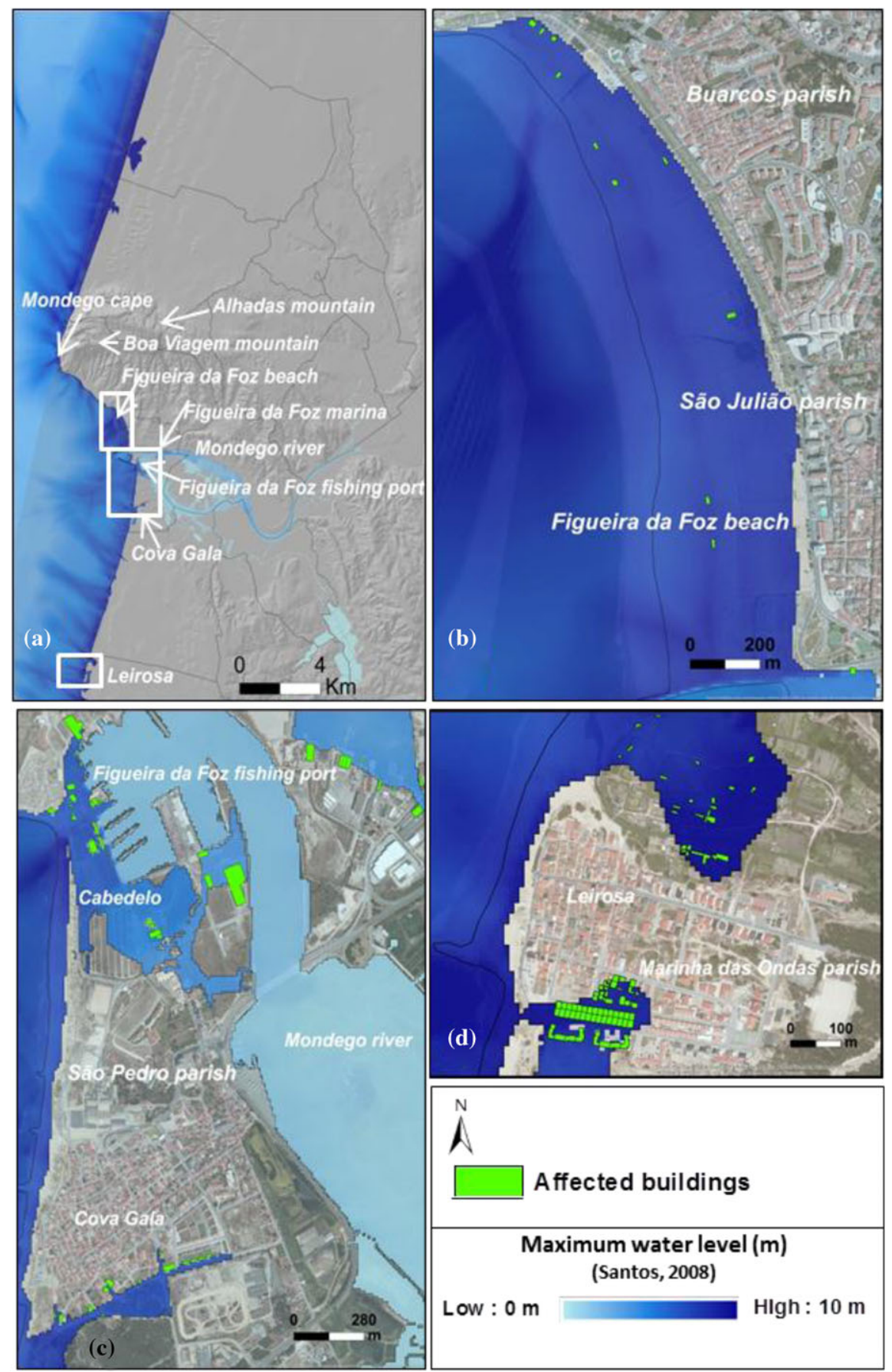

Fig. 2. Tsunami numerical model results (Santos, 2008) and buildings affected in Figueira da Foz municipality.

\subsection{Figueira da Foz Characteristics}

The Figueira da Foz municipality is located in the central coastal region of mainland Portugal and covers an area of $379 \mathrm{~km}^{2}$ (Fig. 1). According to the 2011 Census, ${ }^{(47)}$ the municipality records a population of 62,125 inhabitants, distributed unevenly among 18 parishes, with a population density of 163.3 inhabitants $/ \mathrm{km}^{2}$. In the municipal area, the city 


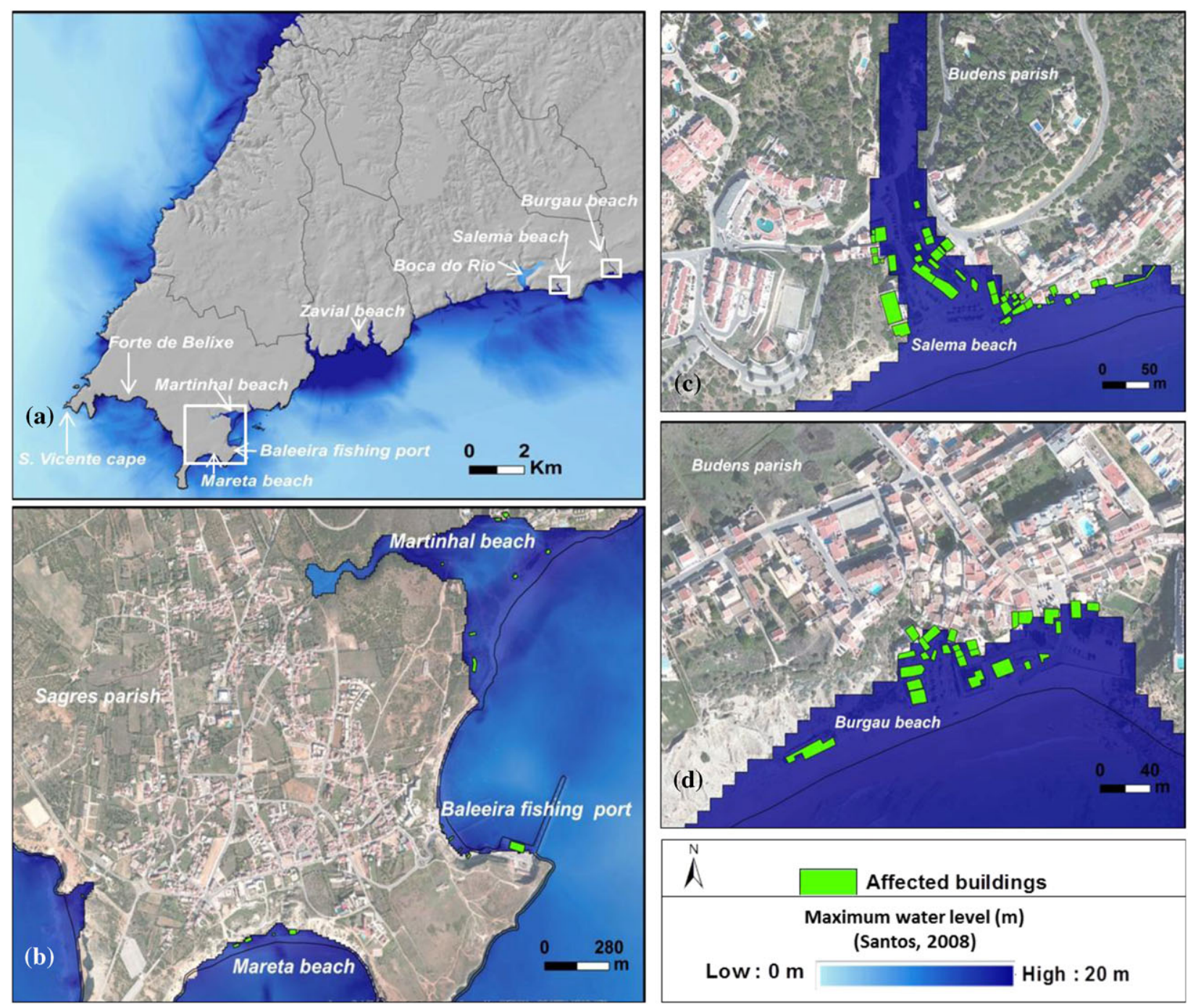

Fig. 3. Tsunami numerical model results (Santos, 2008) and buildings affected in Vila do Bispo municipality.

of Figueira da Foz is a medium-sized city on the national scene, with a total of 28,338 inhabitants, where the seasonality of human occupation is distinct. According to the 2011 Census, ${ }^{(47)}$ the municipality reports a total of 24,893 buildings and 43,300 lodgings, with a higher concentration in the coastal area. In terms of working population, there is a clear predominance of the tertiary sector $(64.9 \%)$, followed by the secondary $(31.6 \%)$ and primary $(3.5 \%)$ sectors. Also noteworthy in the municipal space is the existence of the Figueira da Foz port as a dynamic hub of the local and regional economy.

The altimetry of the study area varies between 0 and $257 \mathrm{~m}$ at the Serra da Boa Viagem (Fig. 2a), which is located in the center of the municipality and stands out in terms of relief, predominating the slopes $<5^{\circ}$, with the highest values located on the northern slopes of the Serra da Boa Viagem (Fig. 2a). The coastline belonging to the municipality of Figueira da Foz is characterized in general terms as a flat, low-altitude area with the exception of Serra da Boa Viagem. To the north of this mountain system there is an extensive coastal plain with well-developed dune formations. ${ }^{(48)}$ The south is also dominated by coastal plains where the Mondego estuary and sand dunes that form frontal dunes begin (Fig. 2a). The Mondego cape area is dominated by cliffs at the base of which a rocky platform abrasion develops. ${ }^{(49)}$ The coastline adjacent to the city of Figueira da Foz is characterized by the existence 
of a beach approximately $500 \mathrm{~m}$ long, the result of sediment retention originating from the north jetty of the port of Figueira da Foz. At the mouth of the Mondego River two jetties help to protect the port area, influencing the adjacent coastline dynamics.

\subsection{Vila do Bispo Characteristics}

The Vila do Bispo municipality comprises the furthest southwest area of the mainland, located in the "Barlavento Algarvio" region and covering an area of $179 \mathrm{~km}^{2}$ (Fig. 1). According to the 2011 Census, ${ }^{(47)}$ the municipality has a population of 5,381 inhabitants, covering a total of five parishes with a low population density of 29.2 inhabitants $/ \mathrm{km}^{2}$. The municipality has a total of 5,184 buildings and 5,979 lodgings. ${ }^{(47)}$ Concerning settlements, Vila do Bispo is the municipality seat, located in the central area of the municipality. Along the coast, Sagres, Burgau, and Salema (Fig. 3) are places of higher population agglomeration. In terms of working population, there is a predominance of the tertiary sector $(81.2 \%)$, followed by the secondary $(11.1 \%)$ and primary sectors $(7.7 \%)$.

The coastline of Vila do Bispo municipality is within the protected area of the Sudoeste Alentejano Natural Park and the "Costa Vicentina," where there are several sediment records of the 1755 Lisbon tsunami in the area, specifically in Boca do Rio. ${ }^{(50)}$ The coastal area has great morphological diversity, dominated by the rocky areas of steep cliffs that are dozens of meters in height, with the dispersed development of sandy areas. Bathing cores often develop in this area (Sagres, Salema, and Burgau; Fig. 3). The altimetry varies between 0 and $150 \mathrm{~m}$ predominating the slopes $<5^{\circ}$ (Fig. 3), where the highest values are located in areas along the coastal cliffs or in areas with steep slopes, which belong to small river systems that flow along the coastline.

\section{METHODOLOGY}

This study presents a new multidimensional methodology that combines four domains of analysis, based on the morphological, structural, social, and tributary components of vulnerability related to tsunamis inundation. The selection of the components was based on several studies: morphologic component, ${ }^{(20-37)}$ structural component, ${ }^{(16)}$ social component. ${ }^{(38,39,41)}$ Finally, we introduce a new component for land allocation based on a property tax. ${ }^{(51)}$
Table II. Morphological Assessment Parameters and Their Weightings (Mv)

\begin{tabular}{lc}
\hline Parameters $\left(P_{n}\right)$ & Weight Factor $\left(W_{n}\right)$ \\
\hline${\text { Morphology of the flooded area }\left(p_{1}\right)}^{\circ}$ & 100 \\
Average slope $^{\circ}\left(p_{2}\right)$ & 76 \\
Distance to coastline $\left(p_{3}\right)$ & 52 \\
Consolidation of geologic materials $\left(p_{4}\right)$ & 38 \\
Land use and land cover $\left(p_{5}\right)$ & 29 \\
\hline
\end{tabular}

This innovative methodological approach has a final CVI that combines the different territorial components. For this purpose, a total of five parameters were collected and analyzed to calculate the morphological component, 13 parameters to calculate the structural component, 47 socioeconomic variables to calculate the social component, and 4 land allocation coefficients to calculate the taxable property component. All vulnerabilities (the four territorial components and the final composite) vary from very low to very high in accordance with the standard deviation $(S D)$ and the following categories: "very low," $<1$ $S D$; "low," $[-1,-0.5 S D]$; "moderate," $[-0.5,+0.5$ $S D$ ]; "high," $[0.5,1 S D]$; "very high," $\geq 1 S D .^{(38)}$

\subsection{Morphological Assessment (Mv)}

The evaluation process related to the morphological component considered the parameters presented in Table II. The analysis and collection of the different attributes belonging to each parameter was performed using a matrix that was based on fieldwork. The morphology of the flooded area resulted from the topographic survey using GPS and was also supplemented with satellite imagery analysis and the use of GIS software. The following parameters - average slope, distance to coastline, land use, and land cover - were analyzed in a GIS environment with data related to the study areas. The parameter consolidation of geologic materials was analyzed with fieldwork conducted by experts on geology of the study area.

The matrix presents a set of intrinsic attributes to each parameter and provides values ranging between +1 and -1 (Table III). The positive values represent an increase in vulnerability and the negative values represent a decrease in vulnerability.

However, not all parameters assume the same influence on the morphological vulnerability assessment. Therefore, it was necessary to assign different weights, with recourse to the effect of the 
Table III. Morphological Vulnerability Assessment Matrix

\begin{tabular}{|c|c|c|c|c|c|}
\hline & +1 & +0.5 & 0 & -0.5 & -1 \\
\hline $\begin{array}{l}\text { Morphology of the } \\
\text { flooded area }\end{array}$ & $\begin{array}{l}\text { Beaches, sandbanks, } \\
\text { sandy ridges, } \\
\text { rocky platforms, } \\
\text { marshes, salines, } \\
\text { rice paddies }\end{array}$ & $\begin{array}{l}\text { Final section of } \\
\text { rivers, coastal } \\
\text { lagoons, coastal } \\
\text { sections with } \\
\text { rocks }>625 \mathrm{~m}^{2}\end{array}$ & $\begin{array}{l}\text { Dune systems, river } \\
\text { banks, and other } \\
\text { morphologies }\end{array}$ & Cliffs with $<20 \mathrm{~m}$ & Cliffs with $>20 \mathrm{~m}$ \\
\hline $\begin{array}{l}\text { Consolidation of } \\
\text { geologic materials }\end{array}$ & $\begin{array}{l}\text { Unconsolidated } \\
\text { sediments, } \\
\text { beaches, } \\
\text { mudslides, landfill }\end{array}$ & $\begin{array}{l}\text { Low-resistant rocks } \\
\text { and rock mass } \\
\text { with visible } \\
\text { discontinuities }\end{array}$ & $\begin{array}{l}\text { Low-resistant rock } \\
\text { and rock mass } \\
\text { with few } \\
\text { discontinuities }\end{array}$ & $\begin{array}{l}\text { Resistant rocks and } \\
\text { rock mass with } \\
\text { visible } \\
\text { discontinuities }\end{array}$ & $\begin{array}{l}\text { Resistant rocks and } \\
\text { rock mass with } \\
\text { few } \\
\text { discontinuities }\end{array}$ \\
\hline Average slope $\left(^{\circ}\right)$ & $<5^{\circ}$ & $5^{\circ}-10^{\circ}$ & $10^{\circ}-20^{\circ}$ & $20^{\circ}-40^{\circ}$ & $>40^{\circ}$ \\
\hline $\begin{array}{l}\text { Distance to } \\
\text { coastline }\end{array}$ & $<50 \mathrm{~m}$ & $50-100 \mathrm{~m}$ & $100-200 \mathrm{~m}$ & $200-300 \mathrm{~m}$ & $>300 \mathrm{~m}$ \\
\hline $\begin{array}{l}\text { Land use and land } \\
\text { cover }\end{array}$ & $\begin{array}{l}\text { Buildings } \\
\text { (residential, } \\
\text { commercial, } \\
\text { industrial, other) }\end{array}$ & $\begin{array}{l}\text { Other artificial } \\
\text { spaces }\end{array}$ & $\begin{array}{l}\text { Predominantly } \\
\text { agricultural } \\
\text { and/or natural } \\
\text { areas, salines }\end{array}$ & & \\
\hline
\end{tabular}

Table IV. Structural Building Assessment Parameters and Their Weightings (Bv)

\begin{tabular}{lc}
\hline Parameters $\left(P p_{n}\right)$ & Weight Factor $\left(W_{n}\right)$ \\
\hline Construction material $\left(\mathrm{pp}_{1}\right)$ & 100 \\
Foundations type $\left(\mathrm{pp}_{2}\right)$ & 97 \\
Emerged building height in relation to the wave $\left(\mathrm{pp}_{3}\right)$ & 95 \\
Built date $\left(\mathrm{pp}_{4}\right)$ & 92 \\
Built form plan $\left(\mathrm{pp}_{5}\right)$ & 75 \\
Hydrodynamics of $\mathrm{r} / \mathrm{c}\left(\mathrm{pp}_{6}\right)$ & 72 \\
Preservations conditions $\left(\mathrm{pp}_{7}\right)$ & 53 \\
Number of floors $\left(\mathrm{pp}_{8}\right)$ & 50 \\
Existence of underground floors $(\mathrm{pp} 9)$ & 47 \\
Occupation form $\left(\mathrm{pp}_{10}\right)$ & 37 \\
Average number of daily visitors or residents per unit of use $\left(\mathrm{pp}_{11}\right)$ & 34 \\
Number of usable units $\left(\mathrm{pp}_{12}\right)$ & 32 \\
Floating occupation $\left(\mathrm{pp}_{13}\right)$ & 29 \\
\hline
\end{tabular}

multicriteria analysis software M-Macbeth ${ }^{\circledR} .(52,53)$ The weights were calculated via pairwise matches between each of the factors (Table II).

The weight assigned to each parameter can vary between 100 (maximum value) and 1 (minimum value). After the weighting of each of the parameters and assigning values to each of its attributes, the morphological vulnerability (Mv) is calculated using the following formula:(16)

$$
\mathrm{Mv}=\frac{\sum_{n=1}^{5} W_{n} P_{n}}{\sum_{n=1}^{5} W_{n}}
$$

where " $P_{n}$ " is the value assigned to each parameter " $n$ " and " $W_{n}$ " is the weight assigned to each parameter. After the calculation of Equation (1), the algo- rithm shown in Equation (2) was used to reschedule the final value for the interval between 0 and 1 :

$$
y=0.5\left(\frac{x}{a}+1\right)^{\log 2 / \log [(b / a)+1]},
$$

where " $x$ " represents the direct value of the vulnerability, " $y$ " is the rescheduled vulnerability value in the range 0 to 1 , " $a$ " is the minimum value of the vulnerability of the sample, and " $b$ " is the maximum value amount of the sample.

\subsection{Structural Building Assessment (Bv)}

With respect to the structural component, the potentially affected buildings were analyzed using the numerical modeling of the tsunami inundation. ${ }^{(43,44)}$ We considered a total of 13 


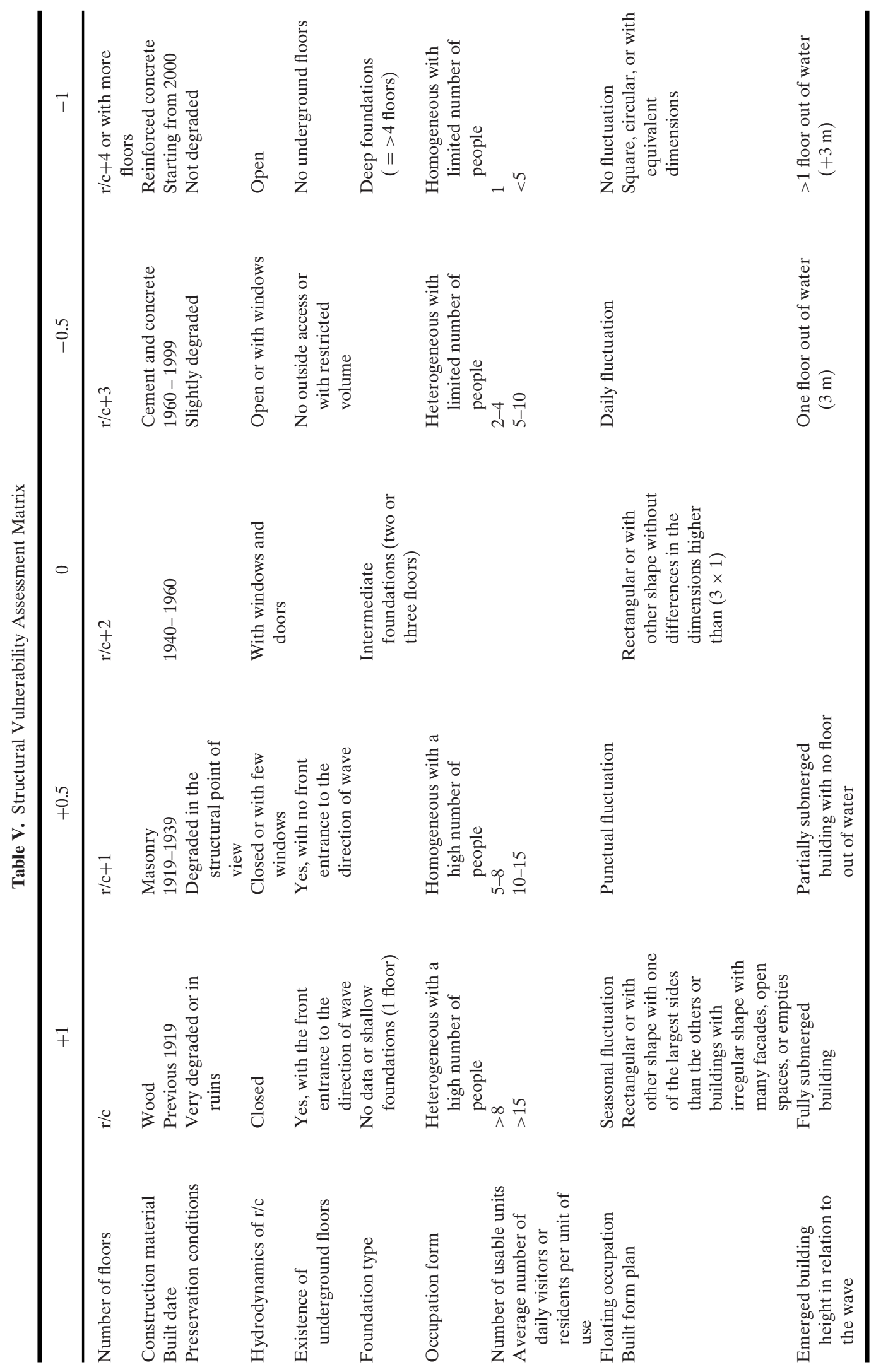


Table VI. Variables Used in the Calculation of Social Vulnerability

\begin{tabular}{|c|c|}
\hline Agriculture & $\begin{array}{l}\text { Proportion of singular farmers over } 65 \text { years of age }(\%) \\
\text { Proportion of natural agricultural producers without any level of education (\%) } \\
\text { Proportion of natural agricultural producers with basic education }(\%)\end{array}$ \\
\hline Buildings and lodgings & 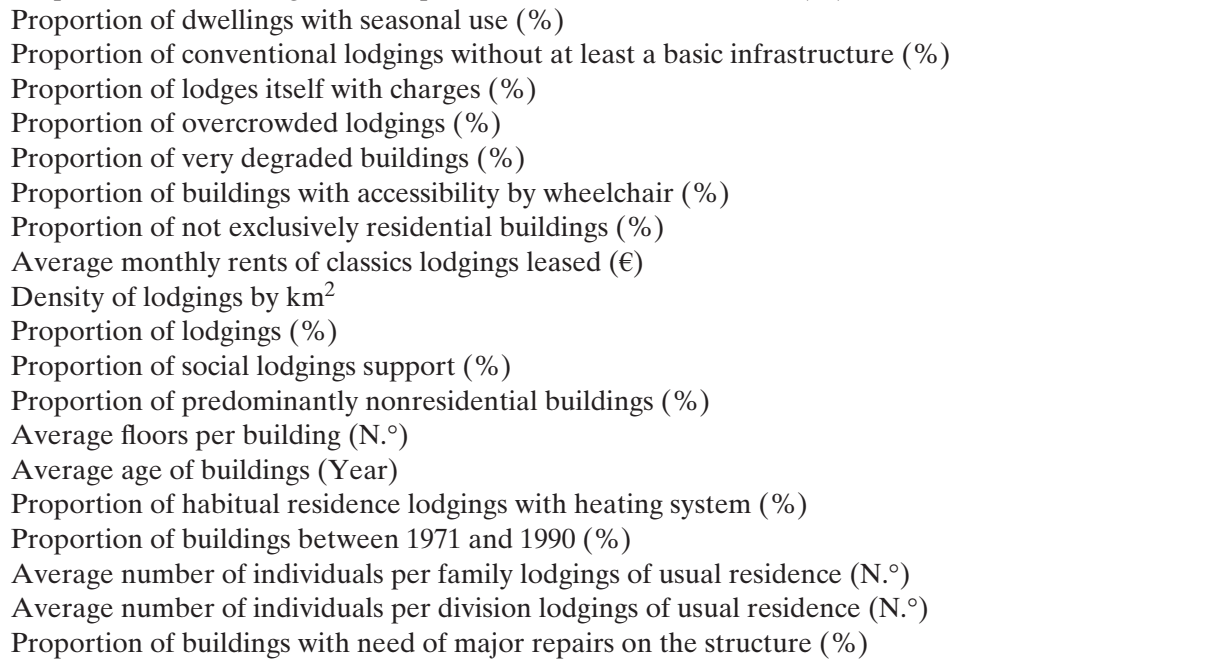 \\
\hline Economy & $\begin{array}{l}\text { Proportion of employed earners population }(\%) \\
\text { Proportion of employed population working in another parish }(\%) \\
\text { Proportion of employed population working or studying in the county }(\%) \\
\text { Proportion of population employed in the primary sector }(\%) \\
\text { Proportion of population employed in the tertiary sector }(\%) \\
\text { Unemployment rate }(\%)\end{array}$ \\
\hline Population & $\begin{array}{l}\text { Proportion of single-parent households }(\%) \\
\text { Proportion of population living in classics lodgings leased (\%) } \\
\text { Variation rate of private households }(2001-2011)(\%) \\
\text { Proportion of the population that } 5 \text { years prior inhabited area outside the municipality ( } \%) \\
\text { Proportion of car use for journeys }(\%) \\
\text { Proportion of population aged } 65 \text { or more years old }(\%) \\
\text { Proportion of resident population with foreign nationality }(\%) \\
\text { Proportion of resident population with age between } 3 \text { and } 5 \text { years attending preschool education (\%) } \\
\text { Longevity index }(\%) \\
\text { Proportion of female population (\%) } \\
\text { Proportion of resident population between } 14 \text { and } 24 \text { years of age }(\%) \\
\text { Proportion of resident population from another parish in the municipality }(\%) \\
\text { Birthrate }(\%)\end{array}$ \\
\hline Services & $\begin{array}{l}\text { Inhabitants per health center and extension }\left(\mathrm{N} .^{\circ}\right) \\
\text { Firefighters per } 1,000 \text { inhabitants } \\
\text { Average stay in hotel establishments }\left(\mathrm{N} .^{\circ}\right)\end{array}$ \\
\hline Social support & $\begin{array}{l}\text { Institutionalized adult population per } 100 \text { inhabitants } \\
\text { Infrastructure of childhood and youth per } 100 \text { inhabitants } \\
\text { Infrastructure for adults per } 100 \text { inhabitants }\end{array}$ \\
\hline
\end{tabular}

parameters (Table IV) that characterize the buildings in their structural, architectural, occupational, and functional aspects. The data acquisition was based on fieldwork conducted using GIS technology (ArcGIS 10.2 [ESRI ${ }^{\circledR}$ ] and Android ${ }^{\circledR}$ ) by using a tablet for data collection in the field. The fieldwork not only allowed the identification of potentially affected buildings but also the collection of the various intrinsic characteristics of the building and surrounding areas. ${ }^{(54)}$

As noted above, we have created a matrix that aggregates all the parameters that comprise the structural aspects of vulnerability. The matrix presents a set of intrinsic attributes to each parameter and provides a value to each attribute ranging between +1 and -1 (Table V). 
New parameters (in bold in Table IV) were introduced in this component that are related to the occupation, functionality, and structure of the buildings, ${ }^{(8-55)}$ which were not covered by previous methodologies, including those presented by Dall'Osso et al. ${ }^{(16)}$ and Ismail et al. ${ }^{(20)}$ The new parameters (built date, existence of underground floors, occupation form, number of usable units, average number of daily visitors or residents per unit of use, and floating occupation) presented in Table IV allow strengthen the analysis, enabling the introduction of new data that were not considered in previous methodologies. These new parameters distinguish the buildings depending on their function, seasonality, in terms of occupation, and understanding how each is used or occupied.

As mentioned previously, because the 13 parameters belonging to the structural component contributed differently to the vulnerability, it was necessary to assign weights using the multicriteria analysis software M-Macbeth ${ }^{\circledR} .{ }^{(52,53)}$ Table IV also shows the parameters presented for the calculation of the structural vulnerability and the weights assigned to each.

After weighting each parameter and assigning values to each of its attributes, the structural vulnerability is calculated $(\mathrm{Bv})$ using the following formula: ${ }^{(16)}$

$$
\mathrm{Bv}=\frac{\sum_{n=1}^{13} W_{n} P p_{n}}{\sum_{n=1}^{13} W_{n}},
$$

where " $P p_{n}$ " is the value assigned to each parameter " $n$ " and " $W_{n}$ " is the weight assigned to each parameter. After the calculation, algorithm (2), mentioned above, is used to reschedule the values that result from the calculation for the interval between 0 and 1 .

\subsection{Social Assessment (Sv)}

To calculate the social vulnerability, a set of 172 variables were analyzed with a disaggregation at the municipality and parish level, collected from the 2011 National Census, ${ }^{(47)}$ the PORDATA database, ${ }^{(56)}$ and the local Social Charter. ${ }^{(57)}$

In this study, the social vulnerability was performed using factor analysis, a methodology applied by several authors, ${ }^{(38,39,58)}$ with some adaptation at the local scale. This methodology is applied using a set of procedures that highlights: the standardization of the variables to $z$-scores, where the average is 0 and the standard deviation is 1 ; a calculation and analysis of the Pearson correlation matrix; the implementation of the factor analysis with the Varimax rotation; an analysis of variance rate parameters (should be greater than 60\%); and an adjustment of the Kaiser-Meyer-Olkin (KMO) sample measurement (should be greater than 0.6), with the elimination of redundant data; and the implementation of principal component analysis (PCA), in which the principal components (FAC) that explain the social vulnerability are extracted. ${ }^{(38,39,58)}$ The variables were interpreted according to their role in explaining vulnerability, where a negative or positive charge indicates the loading component contribution. The analysis was performed at the parish level for two municipalities with a combined total of 23 parishes. To strengthen the analysis it was necessary to enlarge the sample, which required the incorporation of 13 municipalities and a sample of 88 parishes. Thus, the PCA was performed for a total of 172 variables. After performing the data correlation matrix, all the data with a correlation higher than 0.7 were eliminated. The PCA analysis was repeated to achieve a set of parameters with a KMO of 0.717 , with more than 0.6 communalities and a variance rate of $78 \%{ }^{(52)}$ for a set of 47 variables (Table VI). ${ }^{(8)}$

The resulting social vulnerability index (Sv) was produced by summing all factors using equal weighting, according to Cutter et al. ${ }^{(38)}$ and Chen et al. ${ }^{(41)}$ Upon completion of the PCA the above algorithm (Equation (2)) was used to reschedule the values from the calculation that ranged between 0 and 1, according to the previous classifications. Following the recommended classification SoVI ${ }^{\circledR}$ from Cutter et al. ${ }^{(38)}$ the vulnerability was varied according to the standard deviation, as mentioned previously.

\subsection{Taxable Property Assessment (TPv)}

For the analysis of the inferred property value component, a set of four allocation coefficients (housing, commerce, services, and industry) was considered, serving as a basis for calculating the municipal property tax. The inclusion of these data in the tsunami vulnerability assessment complements the analysis process through knowledge of the variation across the territory of different allocation coefficients. These coefficients from the various activities, such as housing, commerce, services, and industry, allow for the classification and differentiation of areas depending on the implanted activities, as well as the improved identification of the various exposed elements. The products of the coefficients mentioned above are used to calculate the TPv. 


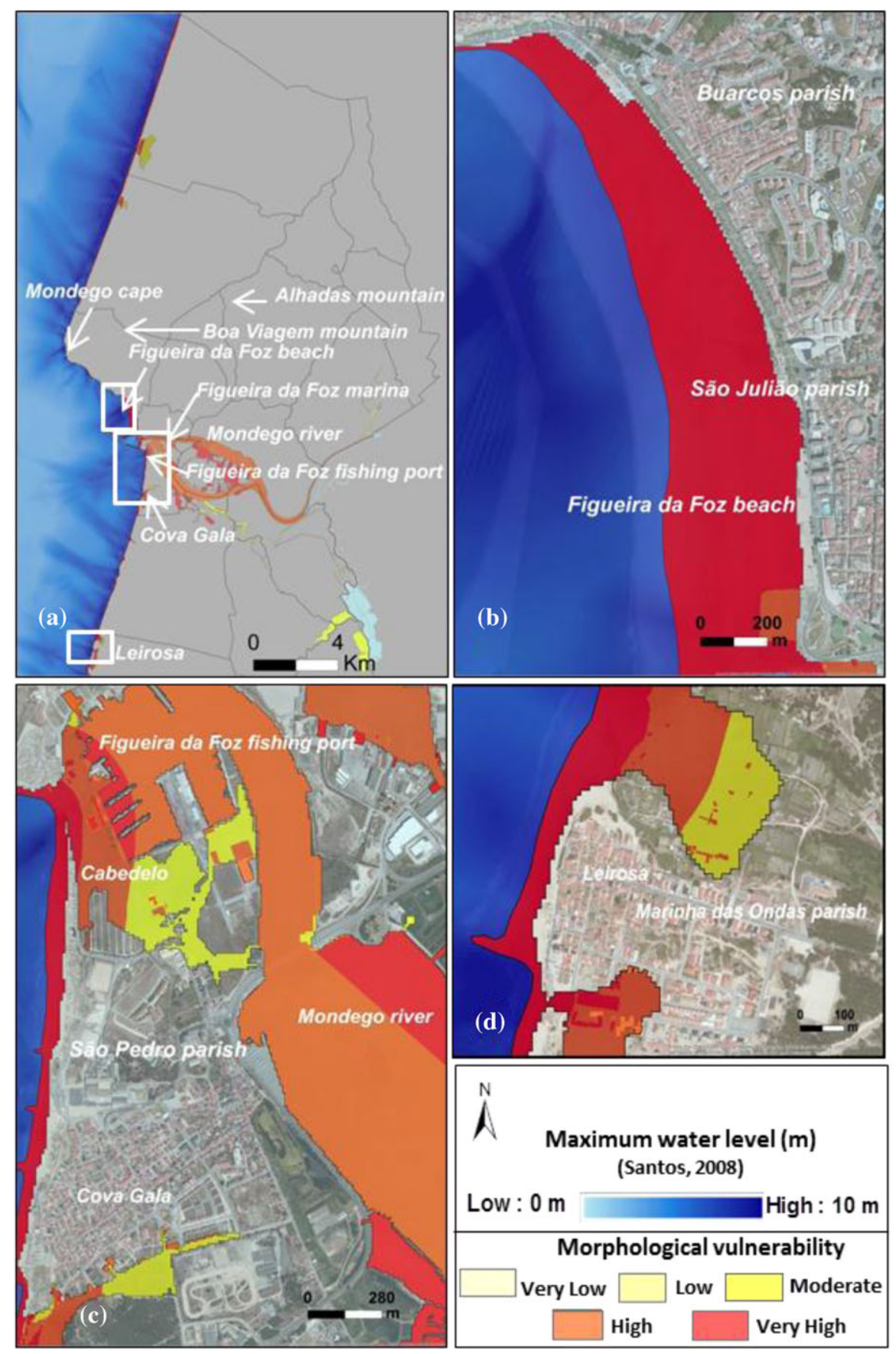

Fig. 4. (a) Morphological vulnerability assessment in Figueira da Foz municipality; (b) details in Buarcos and São Julião parishes; (c) details in São Pedro parish (Cabedelo and Cova Gala); (d) details in Marinha das Ondas parish (Leirosa).

After the calculation is performed, the values were rescheduled for the range between 0 and 1 using Equation (2), resulting in five vulnerability levels based on the standard deviation classes mentioned above.

\subsection{Composite Vulnerability Index}

After calculating the morphological (Mv), structural (Bv), social (Sv), and taxable property vulnerability (TPv), a CVI was calculated, which is the sum of the four components, as presented in Equation (4): 

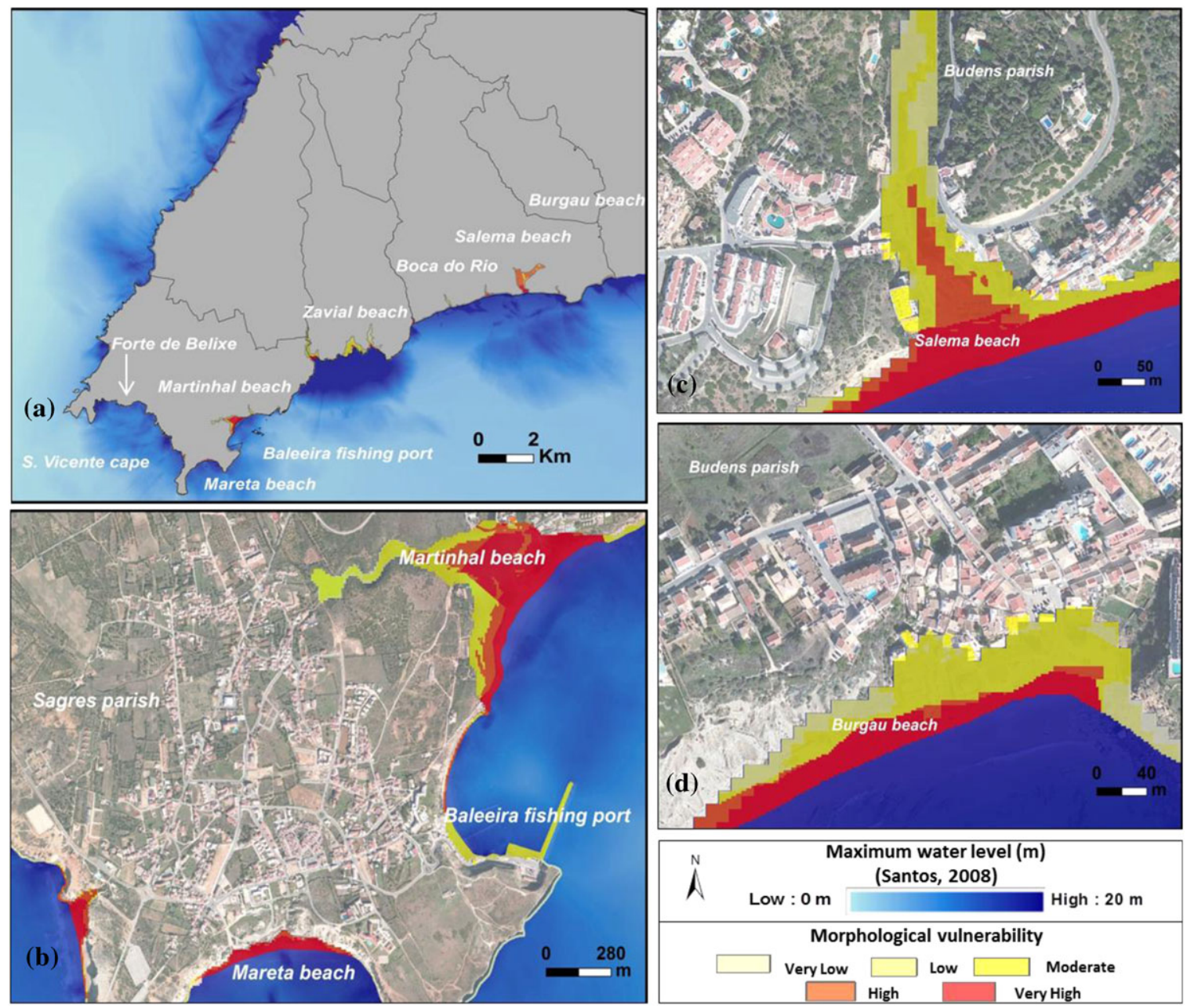

Fig. 5. (a) Morphological vulnerability assessment in Vila do Bispo; (b) details in Sagres parish; (c) details in Budens parish (Salema); (d) details in Budens parish (Burgau).

$$
\mathrm{CVI}=\mathrm{Mv}+\mathrm{Bv}+\mathrm{Sv}+\mathrm{TPv}
$$

The CVI varies between 0 (minimal vulnerability) and 4 (maximum vulnerability), with the vulnerability ranging between very low and very high according to the standard deviation for the five vulnerability levels mentioned above.

\section{RESULTS}

\subsection{Morphological Vulnerability Assessment}

The calculation of the morphological vulnerability shows that it is strongly affected by the distanceto-coastline parameter, resulting in lower vulnerability values with an increase in distance (Fig. 4). This is observable throughout the study areas, particu- larly in Cabedelo, in Figueira da Foz municipality (Fig. 4) and Burgau, in Vila do Bispo municipality (Fig. 5), where the delimitation of morphological vulnerability follows this parameter. However, a more detailed analysis of the two municipalities allows us to observe a different territorial influence of the parameters. With regards to Figueira da Foz, further than the parameter previously mentioned, the morphological vulnerability is also influenced by the existence of river banks as well as flat areas, and narrow channels through the salt marshes, as represented in the estuarine area of Mondego River. For example, the high vulnerability is caused by slope $<2^{\circ}$, the existence of beaches, sand banks, marshes, and rice paddies on the flooded area.

With regards to the municipality of Vila do Bispo, the differentiation of morphological 

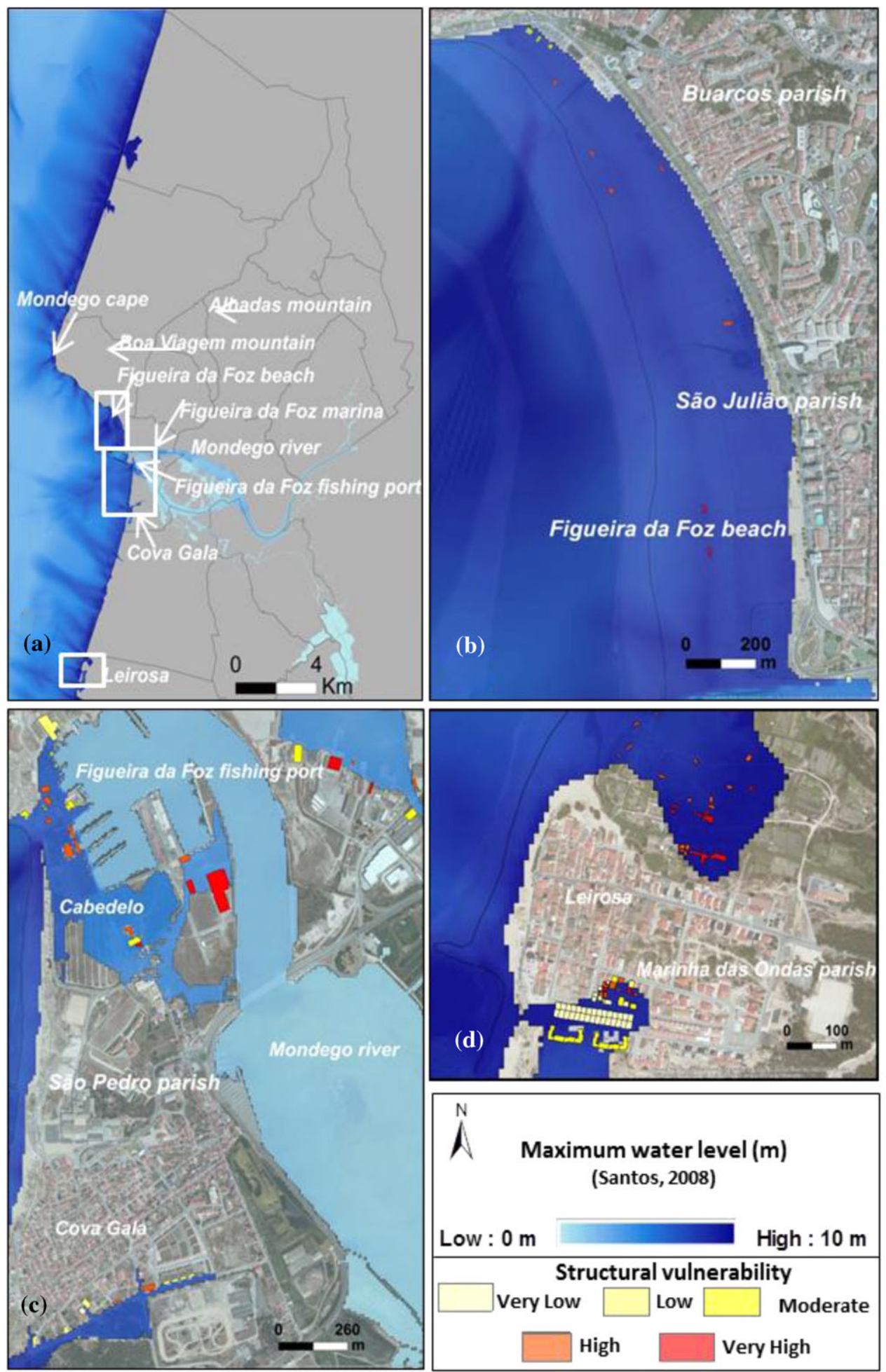

Fig. 6. (a) Structural vulnerability assessment in Figueira da Foz municipality; (b) details in Buarcos and São Julião parishes; (c) details in São Pedro parish (Cabedelo and Cova Gala); (d) details in Marinha das Ondas parish (Leirosa). 

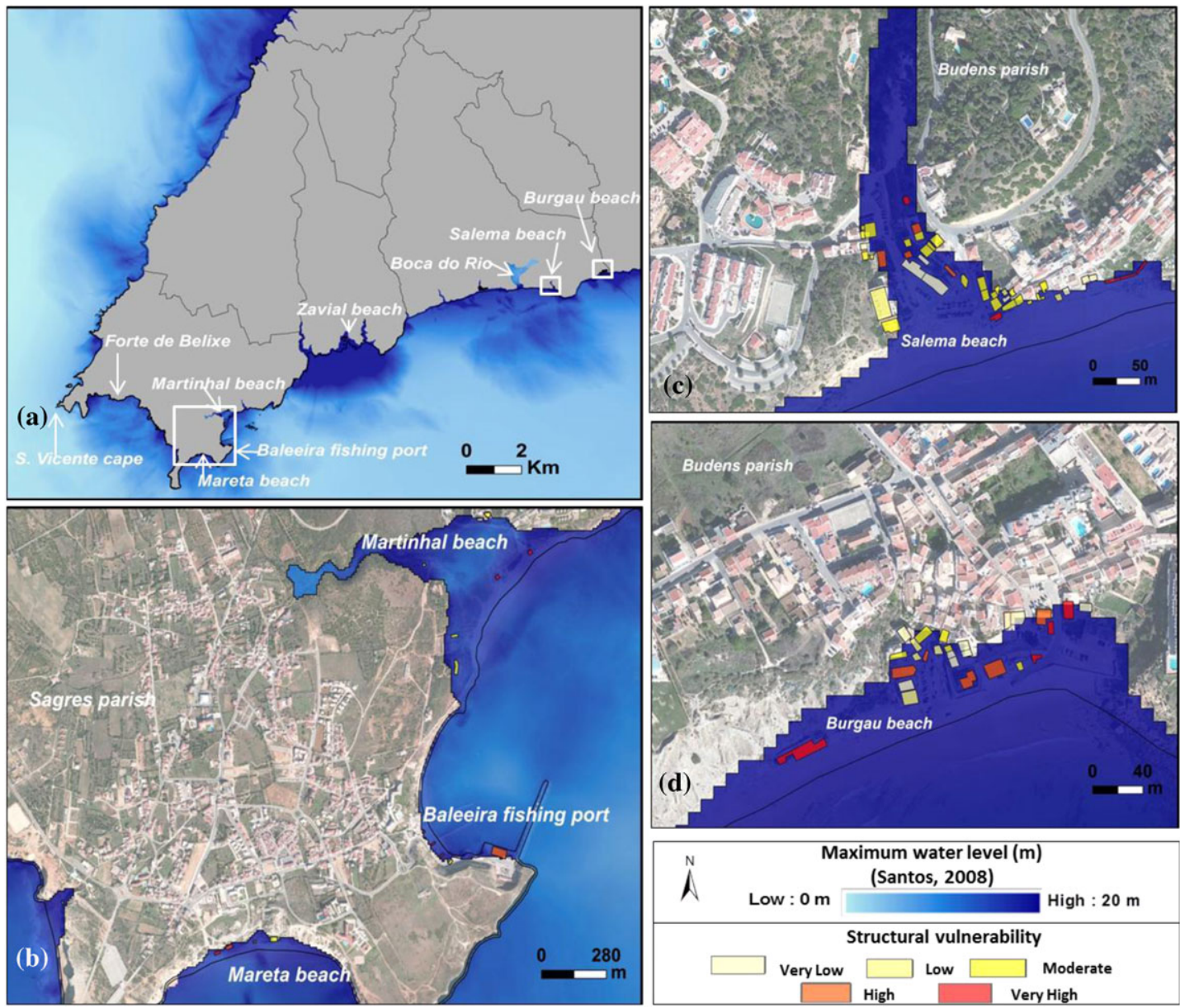

Fig. 7. (a) Structural vulnerability assessment in Vila do Bispo; (b) details in Sagres parish; (c) details in Budens parish (Salema); (d) details in Budens parish (Burgau).

vulnerability results from the parameter distance to coastline. However, in this area, the presence of cliffs and the anthropization of some coastal segments underline the morphology of the flooded area, slope, and land use and land cover parameters, consequently increasing the vulnerability of the analyzed areas (Fig. 5).

In both municipalities, the morphological vulnerability varies between very low and very high levels, with the higher levels along the coastline generally decreasing moving inland.

\subsection{Structural Building Vulnerability Assessment}

In terms of the structural vulnerability, the numerical modeling of the tsunami inundation based on the 1755 Lisbon tsunami identified a total of 244 buildings that are potentially affected in the two studied municipalities. Concerning Figueira da Foz,
144 buildings were identified (Fig. 6), emphasizing the areas of Cabedelo and the port (Fig. 6c), CovaGala (Fig. 6c), and Leirosa (Fig. 6d). The structural vulnerability of the municipality varies between very low to very high, wherein $30 \%$ (43 buildings) have a high vulnerability, 28\% (40 buildings) have a very low vulnerability, 21\% (30 buildings) have a moderate vulnerability, $15 \%$ (21 buildings) have a very high vulnerability, and 6\% (10 buildings) have a low structural vulnerability. Considering only the typology of the buildings, $51 \%$ are exclusively residential, $13 \%$ are annexes/storage, $10 \%$ are commercial buildings, $10 \%$ are warehouses/yards, and $5 \%$ are agricultural buildings. The analysis of the potentially affected buildings shows that the vast majority of the buildings (92\%) are located on the left bank of the Mondego River, which includes Cabedelo with a total of 22 buildings, the port with 
Table VII. Social Vulnerability Components

\begin{tabular}{llc}
\hline FAC & \multicolumn{1}{c}{ Name of Component } & $\begin{array}{c}\text { Explained } \\
\text { Variance (\%) }\end{array}$ \\
\hline 1 & Seasonal occupation & $18.9 \%$ \\
2 & Residential urban centers & $15.5 \%$ \\
3 & Population dynamics & $12.8 \%$ \\
4 & Disadvantaged social contexts & $5.8 \%$ \\
5 & Urban areas with commerce & $4.4 \%$ \\
6 & Population dependent on & $4.3 \%$ \\
& social support \\
\hline
\end{tabular}

10, Cova Gala with 15, and finally Leirosa with 85 buildings.

In the municipality of Vila do Bispo (Fig. 7), a total of 100 buildings were identified, where the structural vulnerability varies between very low and very high. In terms of the number of vulnerable buildings, 39 have a vulnerability that is moderate, 18 are very low, 17 are high, 15 are very high, and 11 are low. In terms of key areas, the Salema beach has 41 buildings (Fig. 7c), Burgau (Fig. 7d) has a total of 25 buildings, and Sagres (Fig. 7b), primarily the Baleeira fishing port area, has a total of 10 buildings. In typological terms, 47 of the buildings are considered to be exclusively residential, 20 have commercial use, and only 8 are of mixed use (residential/commercial).

\subsection{Social Vulnerability Assessment}

Social vulnerability was calculated using factor analysis, which identified a set of 12 components that were used to calculate the vulnerability. The matrix of the components that results from the factorial analysis allowed for the selection of a set of six main components (FAC), which represents $61.7 \%$ of the total variance (Table VII). These FACs were characterized on the basis of the main explanatory variables included therein. The remaining six components were not considered because they contribute with residual values to the total variance, and include explanatory variables also present in the most representative FACs. Next, the six main FACs are presented, and a description is provided of each territorial representation.

\subsubsection{Seasonal Occupation (FAC1)}

The FAC1 represents $18.9 \%$ of the total variance and relates to the seasonal occupation of the territory in question. The main variables in this
FAC are the proportion of the foreign population $(+)$, proportion of the employed population $(-)$, proportion of lodgings $(-)$, proportion of seasonal lodgings $(+)$, and proportion of individuals per lodging ( - . The variables that have a negative sign (-) negatively influence the composition of the FAC. The variables that have positive charge (+) clearly relate to the seasonal occupation of the lodgings, something that occurs in the analyzed areas due their strong seasonal characteristics.

\subsubsection{Residential Urban Centers (FAC2)}

The FAC2 represents $15.5 \%$ of the variance and groups the following variables around it: the proportion of the population employed in the primary sector $(-)$, the average number of floors per building $(+)$, firefighters per 1,000 inhabitants $(-)$, the proportion of single parents $(+)$, the ratio of the female population $(+)$, and the proportion of owner housing $(+)$. The positive and negative loads of variables that comprise the FAC2 translate the urban residential context of the territory. This FAC also represents the economic dimension involved in the purchase/rental of a property and the social dimension translated by identifying two specific groups of a resident population (female population and single parents) that are intrinsically linked to urban residential contexts.

\subsubsection{Population Dynamics (FAC3)}

The FAC3 represents $12.8 \%$ of the variance and relates to the dynamics of the population, presenting as its dominant variables the average monthly housing rents $(+)$, the rate of population change $(+)$, birthrates $(+)$, and the proportion of the population that 5 years prior inhabited areas outside the municipality (+). The variables present in this FAC incorporate population dynamics and growth to the social vulnerability calculation.

\subsubsection{Disadvantaged Social Contexts (FAC4)}

This FAC explains $5.8 \%$ of the variance and has as its primary variables the proportion of individuals per household $(+)$, the proportion of overcrowded households $(+)$, the proportion of the population between 15 and 24 years of age $(+)$, and the unemployment rate $(+)$. The number of unemployed population and population between 15 and 24 years of age are presented as risk groups because of a lack of available financial resources and their family/institutional dependence. In addition, the existence of households with severe disabilities and 


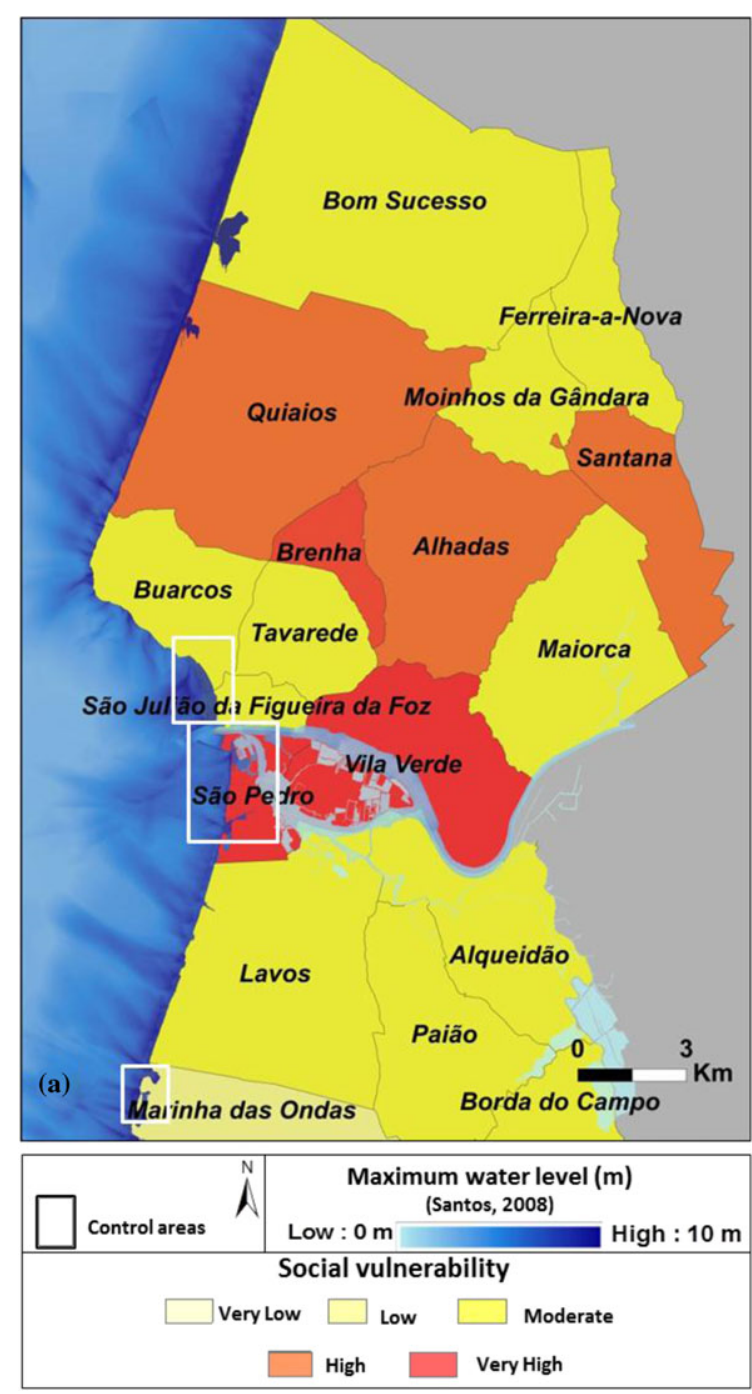

Fig. 8. Social vulnerability in Figueira da Foz municipality.

overcrowded housing influence the vulnerability and local carrying capacity.

\subsubsection{Urban Areas with Commerce (FAC5)}

The primary variables that integrate the FAC5 are the proportion of predominantly residential buildings $(+)$, the proportion of buildings that are not exclusively residential $(+)$, and the proportion of the population working in another parish $(-)$. This FAC contributes $4.4 \%$ to the variance. The first two variables have a positive charge and are closely related to an urban context with a strong commercial bias. The proportion of the population working in another parish has a negative charge, which indicates that the

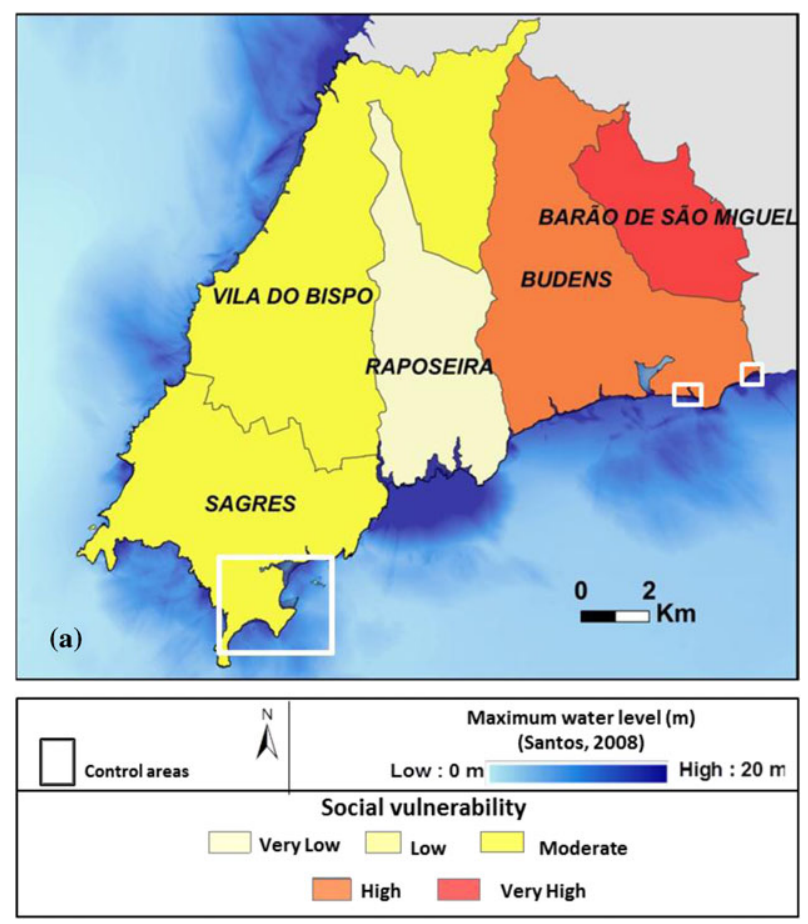

Fig. 9. Social vulnerability in Vila do Bispo municipality.

resident population primarily works in the parish of residence.

\subsubsection{Population Dependent on Social Support (FAC6)}

The FAC6 possesses the following variables: social support housing $(+)$, adult population support institutions $(+)$, child-care institutions $(+)$, and the longevity index $(+)$, contributing $4.3 \%$ to the total variance. This FAC clearly identifies two risk groups: elderly and young people. These two groups have a high vulnerability caused by several factors, in particular the family/institutional dependence and reduced physical mobility.

In spatial terms, the social vulnerability was calculated for all parishes of the municipalities being studied. In the Figueira da Foz municipality (Fig. 8), with 18 parishes, the social vulnerability varies between a low and very high level. Those areas potentially most affected are Cabedelo, Cova Gala, and the industrial port of Figueira (parish of S. Pedro; Fig. 8), which have a very high social vulnerability. Leirosa village, located in the southern part of the municipality (Marinha das Ondas parish; Fig. 8), has a low vulnerability. 

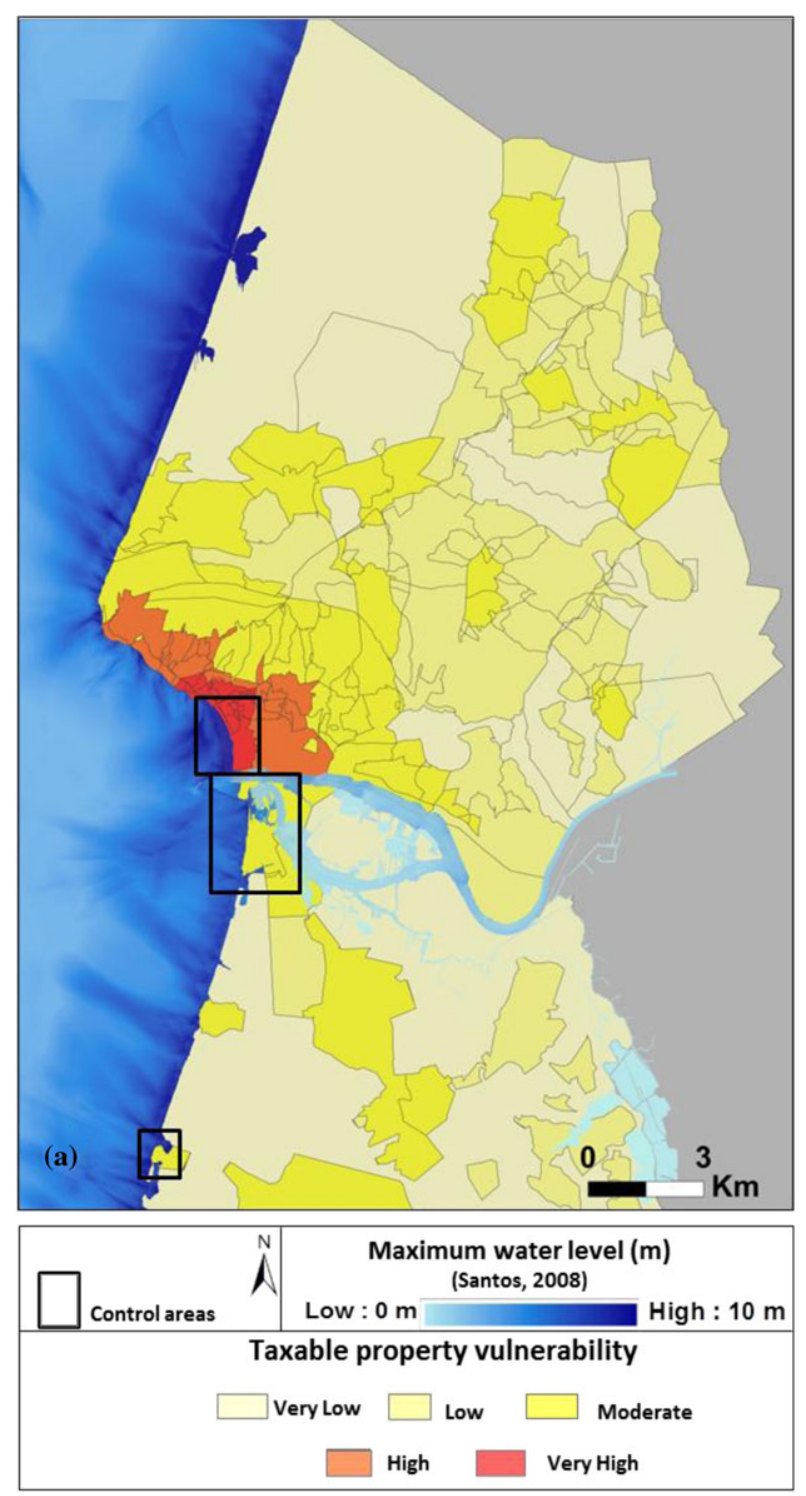

Fig. 10. Taxable property vulnerability in Figueira da Foz municipality.

In Vila do Bispo municipality (Fig. 9), the social vulnerability varies between a very low and very high level. In terms of the potentially most affected areas, Sagres (Fig. 9) has a moderate vulnerability, and Salema and Burgau (Fig. 9), both located in Budens parish, have a high social vulnerability.

\subsection{Taxable Property Vulnerability Assessment}

With regards to Figueira da Foz, the taxable property vulnerability ranges from a very high to very low level with marked differences along the

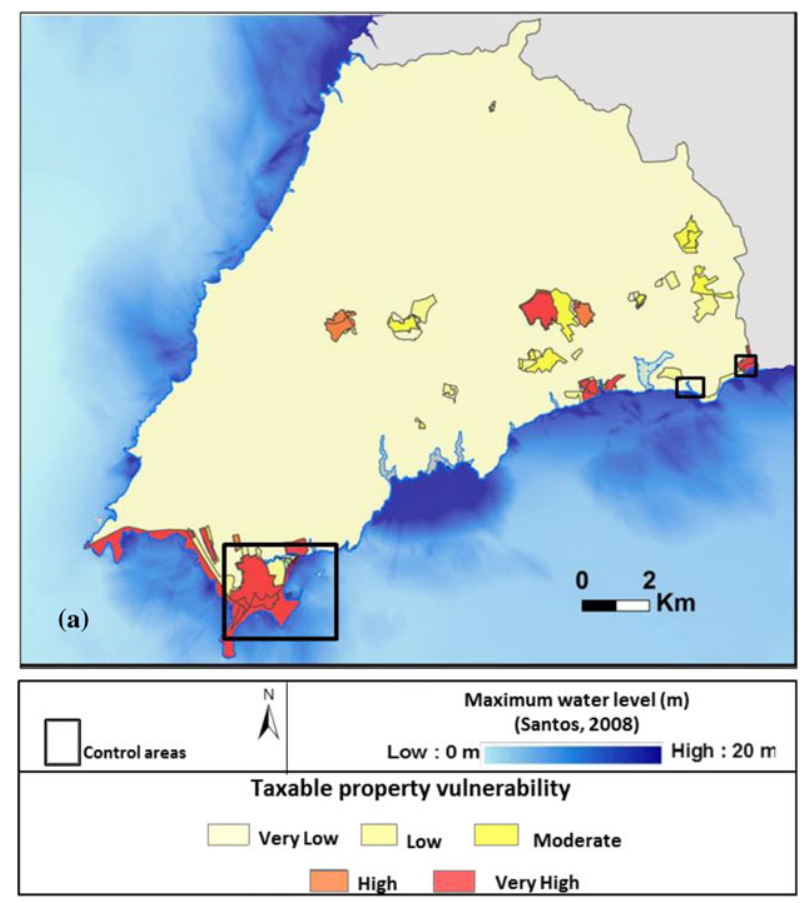

Fig. 11. Taxable property vulnerability in Vila do Bispo municipality.

municipal area. If we analyze only the potentially flooded areas, the highest values are observed in Buarcos and S. Julião (Fig. 10) because they are in the presence of consolidated urban areas where the coefficients are higher.

In contrast, the lowest values are found to be associated with rural areas (forest and agriculture dominance) and natural areas. In the Cabedelo area and the port (Fig. 10), the allocation coefficient has the same value, with each having a moderate vulnerability.

In the Vila do Bispo municipality, the taxable property vulnerability also varies between a very low and very high level. By analyzing potentially flooded areas a clear distinction is found between urban and natural/rural areas. The areas of Sagres, Baleeira port, and the Martinhal coastal sector have the highest values of vulnerability (Fig. 11). The areas with the lowest values are those that are least developed, expressing a clear natural/rural predominance. The Burgau area (Fig. 11) has a high taxable property vulnerability because it is a consolidated beach resort with some urban pressure, where the different allocation coefficients experience an increase. 

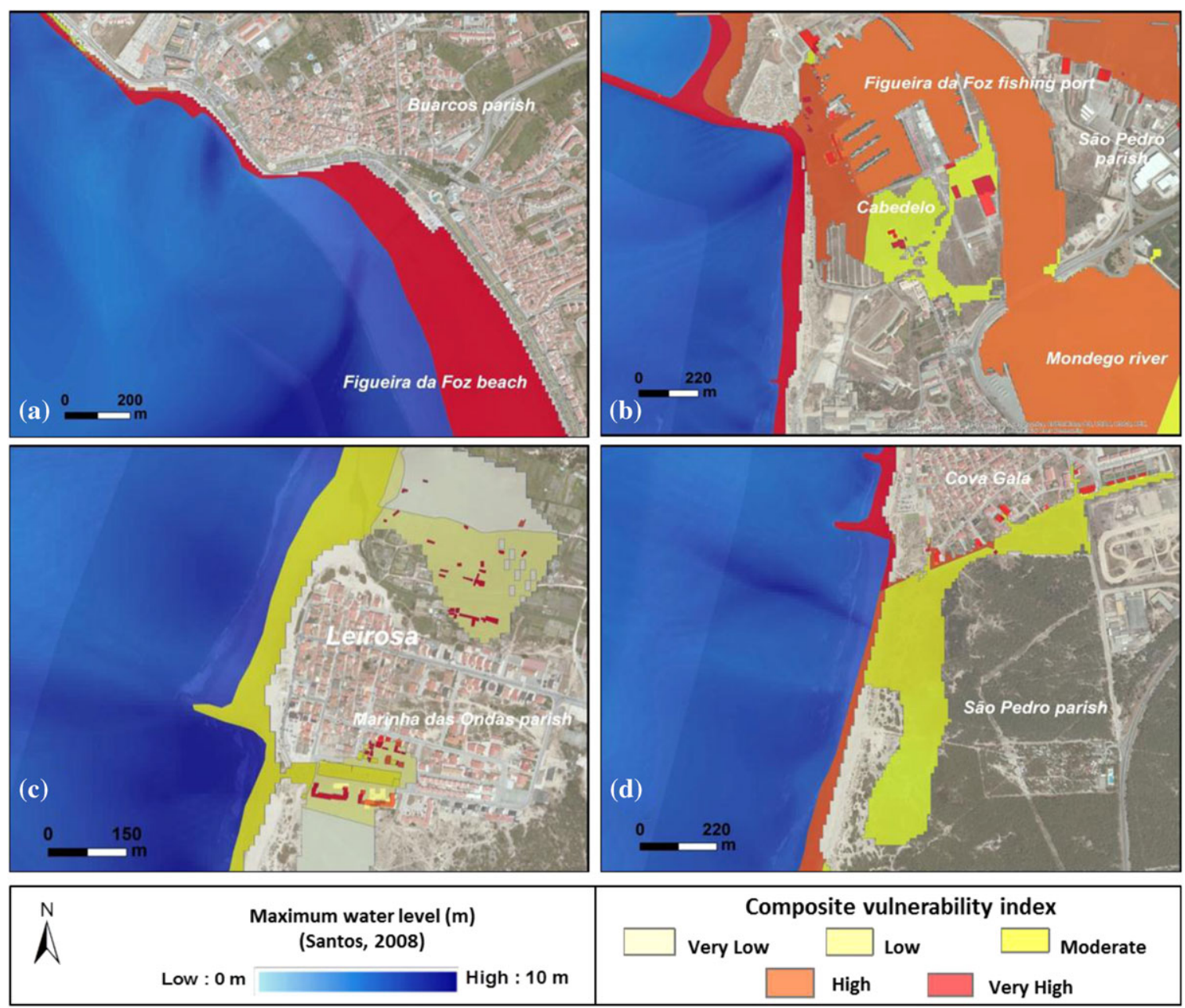

Fig. 12. (a) CVI details in Buarcos and São Julião parishes; (b and d) CVI details in São Pedro parish (Cabedelo and Cova Gala); (c) CVI details in Marinha das Ondas parish (Leirosa).

\subsection{Composite Vulnerability Index}

After calculating the morphological, structural, social, and taxable property vulnerabilities the CVI that results from the combination of these components is calculated.

The CVI results for Figueira da Foz (Fig. 12) present a mean value of 1.95 with a standard deviation of 0.29 . The highest values occur along the coast and there is a reduction in vulnerability further inland in the study area. Noteworthy is the fact that the CVI is strongly influenced by the morphological and structural characteristics of the area. With regards to the different levels of the CVI for Figueira da Foz, the levels vary from very low to very high. Six percent of the area is classified as very high, corresponding to buildings and coastal areas, especially the parishes of
Buarcos, São Julião, and São Pedro (Fig. 12(a)-(c)). The high vulnerability levels occur in small coastal sectors and salines. Forty-three percent of the area has a moderate vulnerability, especially the coastal area in the north of Quiaios and in the south of Cova Gala (Fig. 12(c)). The moderate CVI is also featured in the Mondego riverside zones, and the Figueira da Foz port and marina. The inland areas and estuarine Mondego areas have low and very low CVI levels. The southern area of Leirosa also features a low or very low CVI, primarily a result of the vulnerability of the morphological and taxable properties (Fig. 12(d)).

With regards to the municipality of Vila do Bispo (Fig. 13), the results show a CVI mean value of 1.76, with a standard deviation of 0.33 . In general, the 

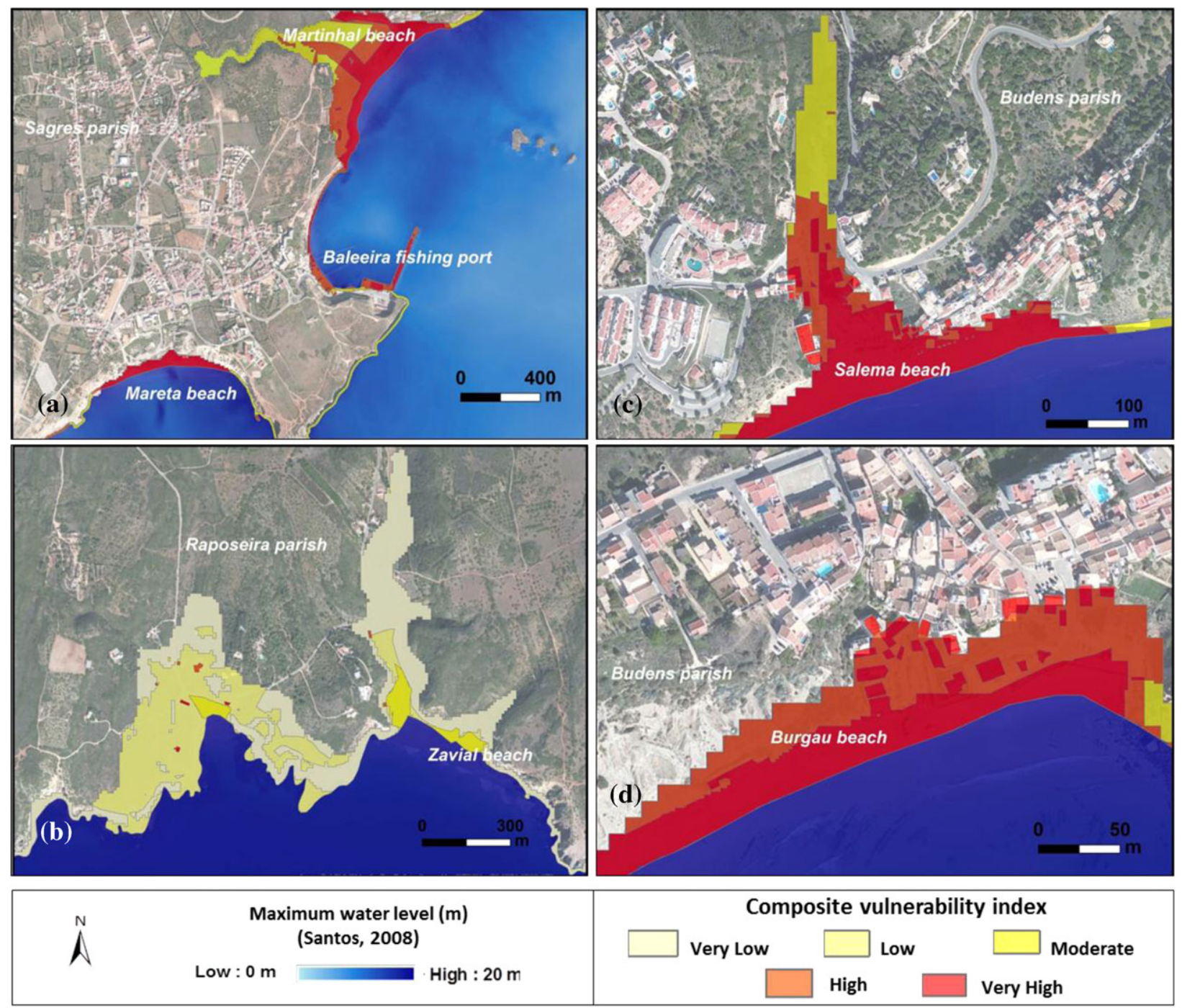

Fig. 13. (a) CVI details in Sagres parish; (b) CVI details in Raposeira parish (Zavial); (c) CVI details in Budens parish (Salema); (d) CVI details in Budens parish (Burgau).

highest CVI values are associated to coastal areas with low elevation (e.g., Boca do Rio) or within urban cores (Sagres, Salema, and Burgau), with $9 \%$ of the area corresponding to very high levels and $22 \%$ corresponding to high vulnerability levels. Thirtyone percent of the study area features a moderate CVI, primarily in coastal sections where there is a transition between sandy beaches and cliffs. Finally, the low (23\%) and very low (15\%) vulnerabilities correspond to coastal areas dominated by cliff slopes and inland sectors. The CVI analysis demonstrated that it is heavily influenced by morphological characteristics, especially the "slope" and "land use and cover" parameters, as well as by the taxable property and social component of vulnerability.

\section{DISCUSSION}

The results obtained in this study respond to the concerns raised by Wisner et al., ${ }^{(10)}$ Atillah et al., ${ }^{(6)}$ and Tavares et al., ${ }^{(60)}$ in which the authors emphasize the importance of territorial vulnerability. Thus, this study provides a more reliable perspective of the costal area's exposure to a potential tsunami event related to physical, social, economic, and critical infrastructure, as indicated by Refs. 16, 19, and 28. 
Fig. 14. Graphical representation of the vulnerability for (a) Figueira da Foz municipality and (b) Vila do Bispo municipality.
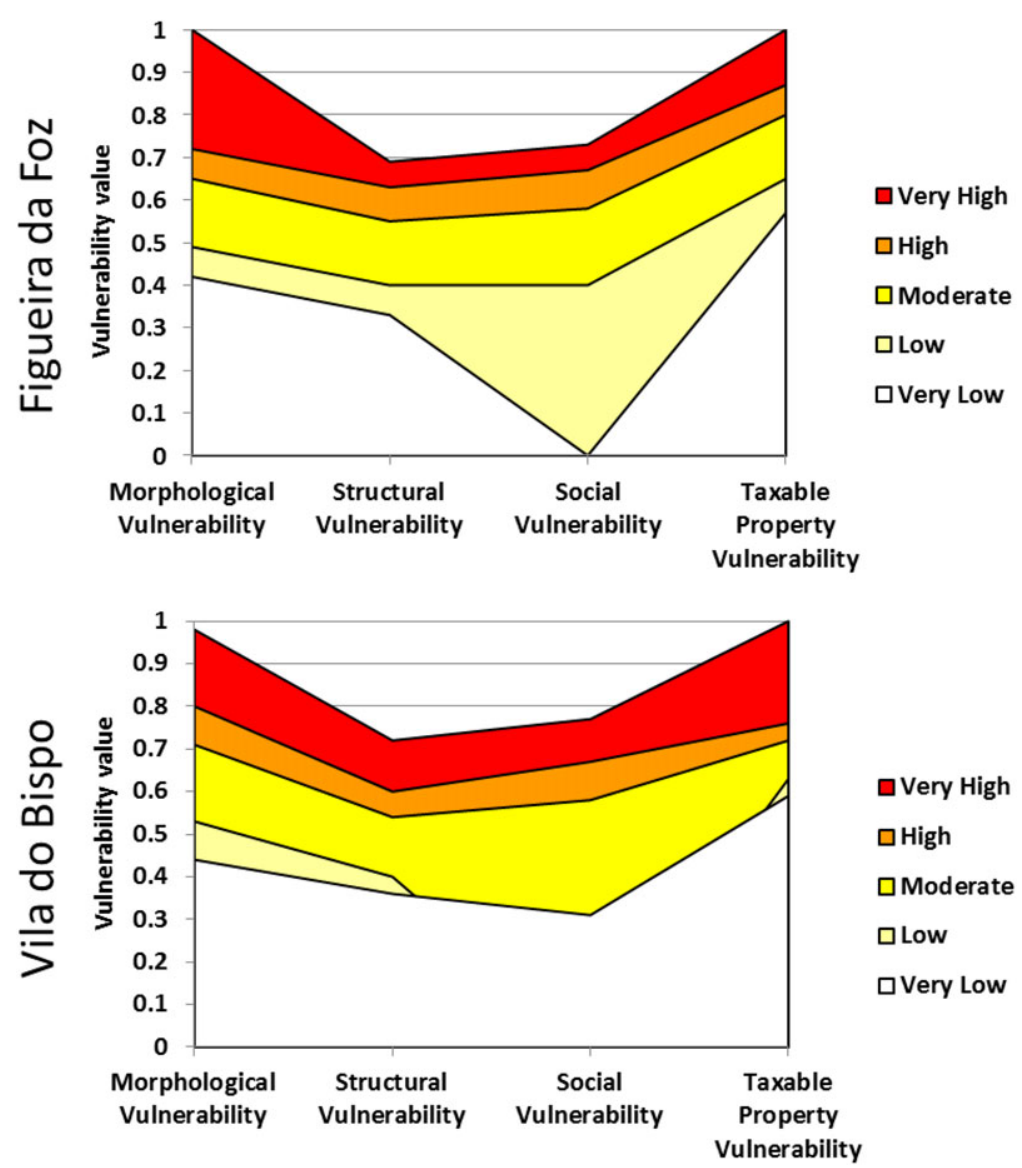

Fig. 14 summarizes a graphical representation of each of the vulnerability classes obtained for the morphological, structural, social, and taxable property components in the two studied areas, which show different representations of vulnerability. The $\mathrm{y}$-axis represents the maximum and minimum values for each vulnerability class. The figure shows that in both areas lower rates for the structural and social vulnerabilities are observed when compared with the morphological and taxable property vulnerabilities. In the Vila do Bispo municipality, a wide representation is presented of the very high and moderate levels for the four components of vulnerability. A very low level of social vulnerability is absent in Figueira da Foz, compared with no representation of low-level social vulnerability in Vila do Bispo. Those results represent a different importance of components that explains the vulnerability and highlights the territorial differences, namely, for the lower classes of social vulnerability.

These results also demonstrate that the vulnerability is marked by local characteristics intrinsic to the territory, whether morphological, social, or taxable in nature. However, the vulnerability is not stressed by the structural characteristics of the buildings in the territory, which represent a deepening in relation to previous methodologies. This finding supports the importance of a composite multidimensional analysis, improving upon the methodologies developed by Cutter et al., ${ }^{(38)}$ Dall'Osso et al., (16) and Santos, Tavares, and Emidio. ${ }^{(28)}$

This work also notes, in relation to other studies, that coastal areas with high vunerability to tsunami, given their flat morphology, can translate exposed areas with different composite vulnerability, depending on the land use and land occupation, as well as, the social functions existent there or economic activities taking place in flooded or neighboring areas.

This framework is also represented in Fig. 15. In both graphics, the percentages of the area for each vulnerability class in both municipalities are presented. The results demonstrate the representation of the contrasted area for the morphological, structural, and social vulnerabilities. This contrast is not 

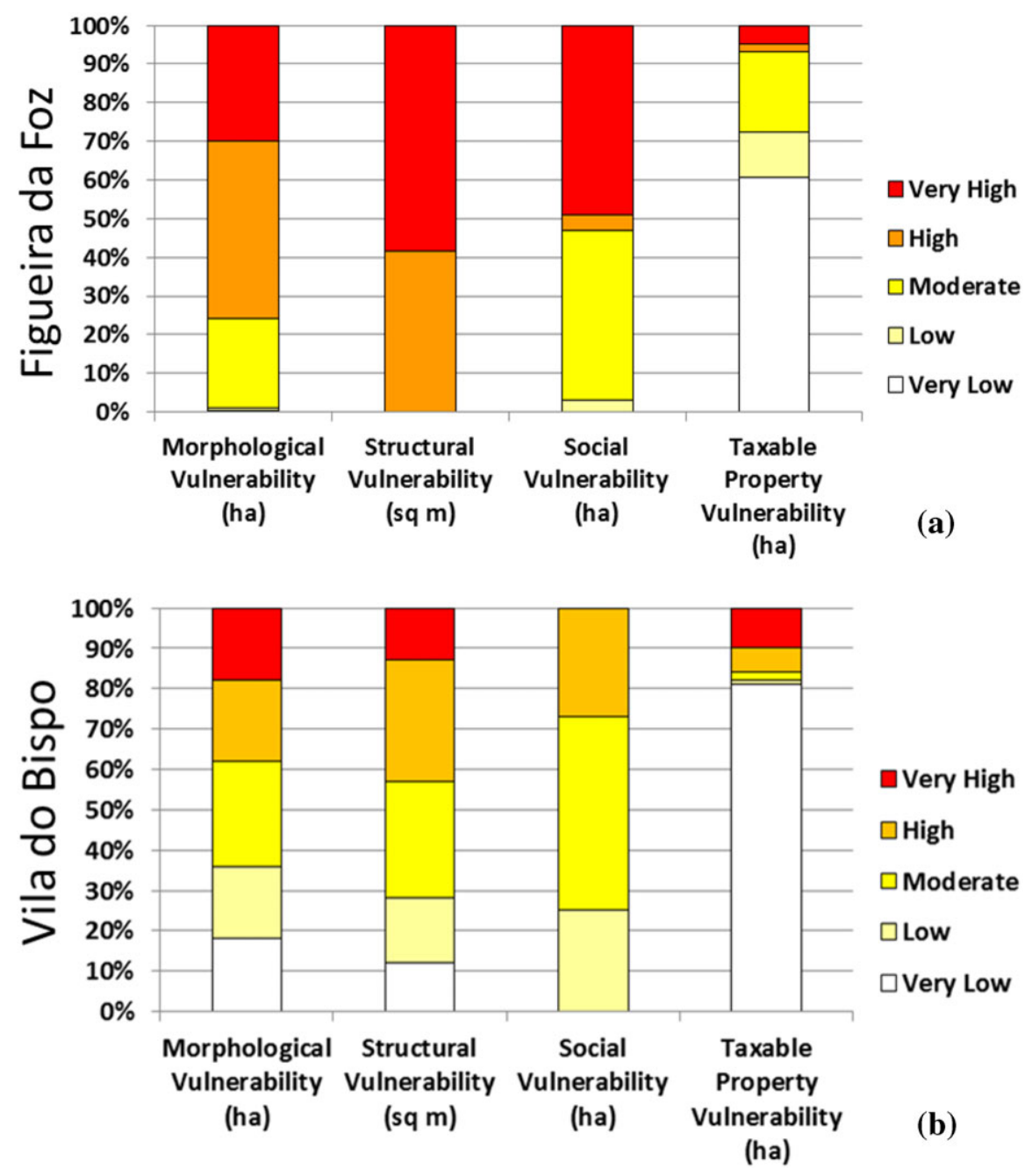

Fig. 15. Relationship between different classes of vulnerability and the corresponding percentage of area: (a) Figueira da Foz municipality and (b) Vila do Bispo municipality.

as evident for the taxable property vulnerability. In both municipalities, the area expressed by this vulnerability (very low and low classes) represents more than $60 \%$ of the affected area. This occurs because this area is expressed as a component normalized for the entire country, without local specificities. In addition, Fig. 15 also shows that Figueira da Foz exhibits a broad representation of the area with the highest morphological $(30 \%)$, structural $(57 \%)$, and social (48\%) vulnerabilities values compared with Vila do Bispo municipality (morphological [17\%], structural $[13 \%]$, and social $[0 \%])$. These differences demonstrate the importance of having different components in the territorial assessment.

The cartography presented in Figs. 12 and 13 shows that the CVI has spatial differences. In gen- eral, the CVI decreases as the distance to the shoreline increases, with the exception of coastal segments with cliffs.

Furthermore, the CVI cartography also demonstrated some territorial specificities. Thus, in Figueira da Foz municipality, where the CVI is fundamentally characterized by a morphological and tax component of vulnerability, in contrast to Vila do Bispo beyond the two components mentioned above, the social component also plays an important role in the final CVI value. It should also be noted that, in general terms, the Vila do Bispo municipality presents a higher CVI compared to Figueira da Foz. This may be a result of the percentage of the area occupied by the two higher classes of vulnerability $(31 \%$ in Figueira da Foz and 23\% in Vila do Bispo). 
One interesting outcome of the CVI results is highlighted by the presence of the buildings. There is a high level of vulnerability among the buildings for both municipalities. These results are in agreement with the other methodologies, ${ }^{(13,16,20)}$ which mostly express the buildings' structural vulnerability.

\section{CONCLUSIONS}

In our approach, new parameters were considered for the assessment of structural vulnerability that strengthens the analysis and distinguishes the potentially affected buildings based on a broad set of variables. However, contrary to previous methodologies, this work demonstrated that it is possible to assess the vulnerability of the territorial context of buildings.

In addition, the improvement featured using this methodology is also supported by the inundated areas obtained from the tsunami numerical model. This allows for a detailed evaluation of all the territorial components that contribute to the vulnerability.

This methodology can also be applied to coastal areas characterized by high energy, causing overtopping and flooding during storms. ${ }^{(61)}$ The focus given to different components to assess the territorial vulnerability for areas with intense occupation, location of critical infrastructure, and environmental values allows the definition of prevention and mitigation measures. ${ }^{(60-64)}$

The process is practical to apply, and with the change of attribute of the different parameters presented for each matrix, can be applied to other geographical contexts, highlighting local characteristics, particularly in terms of morphology, land use, and occupation. The various outputs resulting from the application of the methodology adopted in this study can and should serve as a tool for the different stakeholders, enabling them to discuss and implement measures for the prevention, reduction, and mitigation of tsunami inundation. The collected data were based on field work, remote sensing imagery interpretation, and the analysis of a collection of a wide range of data from census databases, which may be observed as a challenge for other studies in potentially affected coastal areas.

This methodology can be applied to other geographical contexts and is not dependent on past historical damages. The results can contribute to assisting in the emergency management process by identifying the most vulnerable areas and potentially affected buildings. The results obtained in this study can also be an important basis for the definition of evacuation routes, the site selection of shelter locations and buildings with vital societal functions, improve a tsunami warning system, ${ }^{(65)}$ and also the definition of spatial planning policies.

\section{ACKNOWLEDGMENTS}

This research was supported by the TsuRiMa Project - TSUnami RIsk MAnagement for spatial planning and civil protection (PTDC/CSGEO/ 118992/2010), funded by the Foundation of Science and Technology (FCT), Portugal.

\section{REFERENCES}

1. Dominey-Howes D, Papathoma M. Validating a tsunami vulnerability assessment model (the PTVA model) using field data from the 2004 Indian Ocean tsunami. Natural Hazards, 2007; 40:113-136.

2. Reese S, Bradley BA, Bind J, Smarta G, Powerc W, Sturmana J. Empirical building fragilities from observed damage in the 2009 South Pacific tsunami. Earth-Science Reviews, 2011; 107:156-173.

3. Leone F, Lavigneb F, Parisc R, Denaina JC, Vineta F. A spatial analysis of the December 26th, 2004 tsunami-induced damages: Lessons learned for a better risk assessment integrating buildings vulnerability. Applied Geography, 2011; 31:363-375.

4. Koshimura S, Hayashib S, Gokonb H. The impact of the 2011 Tohoku earthquake tsunami disaster and implications to the reconstruction. Soils and Foundations, 2011; 54:560-572.

5. Bryant E. Tsunami "the Underrated Hazard." Melbourne: Cambridge University Press; Springer International Publishing AG, 2014.

6. Atillah A, El Hadani D, Moudni H, Lesne O, Renou C, Mangin, A, Rouffi F. Tsunami vulnerability and damage assessment in the coastal area of Rabat and Salé, Morocco. Natural Hazards and Earth System Sciences, 2011;11:3397-3414.

7. Freire S, Aubrecht C, Wesgscheider S. Advancing tsunami risk assessment by improving spatio-temporal population exposure and evacuation modeling. Natural Hazards, 2013; 68:1311-1324.

8. Barros JL, Emídio A, Santos A, Tavares AO. Composite methodology for tsunami vulnerability assessment based on the numerical simulation of 1755 Lisbon tsunami Application on two Portuguese coastal areas. Pp. 15811588 in Nowakowski T, Młyńczak M, Jodejko-Pietruczuk A, Werbińska-Wojciechowska S. (eds). Safety and Reliability: Methodology and Applications. London: Taylor \& Francis Group, 2015.

9. Freiria S, Tavares AO, Julião RP. The multiscale importance of road segments in a network disruption scenario: A riskbased approach. Risk Analysis, 2015; 35(3):484-500.

10. Wisner B, Blaikie P, Cannon T, Davis I. At Risk: Natural Hazards, People's Vulnerability and Disasters, 2nd ed. London and New York: Routledge, Taylor \& Francis Group, 2004.

11. INAG. Estatégia Nacional para a Gestão Integrada da Zona Costeira: Lisboa: Instituto da Água, 2009.

12. Douglas J. Physical vulnerability modelling in natural hazard risk assessment. Natural Hazards and Earth System Science, 2007; 7:283-288.

13. Papathoma M, Dominey-Howes D, Zong Y, Smith D. Assessing tsunami vulnerability, an example from Herakleio, Crete. Natural Hazards and Earth System Sciences, 2003; 3:377-389. 
14. Papathoma M, Dominey-Howes, D. Tsunami vulnerability assessment and its implications for coastal hazard analysis and disaster management planning, Gulf of Corinth, Greece. Natural Hazards and Earth System Sciences, 2003; 3:733-747.

15. Ghobarah A, Saatcioglub M, Nistorb I. The impact of the 26 December 2004 earthquake and tsunami on structures and infrastructure. Engineering Structures, 2006; 28:312-326.

16. Dall'Osso F, Gonella M, Gabbianelli G, Withycombe G, Dominey-Howes D. A revised (PTVA) model for assessing the vulnerability of buildings to tsunami damage. Natural Hazards and Earth System Sciences, 2009; 9:1557-1565.

17. Dall'Osso F, Maramai A, Graziani L, Brizuela B, Cavalletti A, Gonella M, Tinti S. Applying and validating the PTVA-3 model at the Aeolian Islands, Italy: Assessment of the vulnerability of buildings to tsunamis. Natural Hazards and Earth System Sciences, 2010; 10:1547-1562.

18. Birkmann J, Teichman K, Welle T, González M, Olabarrieta $\mathrm{M}$. The unperceived risk to Europe's coasts: Tsunamis and the vulnerability of Cadiz, Spain. Revista Crítica de Ciências Sociais, 2011; 93:129-165.

19. Tarbotton C, Dominey-Howes D, Goff J, Papathoma-Kohle M, Dall'Osso F, Turner I. GIS-based techniques for assessing the vulnerability of buildings to tsunami: Current approaches and future steps. Pp. 115-126 in Terry J, Goff J (eds). Natural Hazards in the Asia-Pacific Region: Recent Advances and Emerging Concepts. London: Geological Society of London, 2012.

20. Ismail H, Abd Wahab A, Mohd Amin M, Mohd Yunus M, Jaffar Sidek F, Esfandier JB. A 3-tier tsunami vulnerability assessment technique for the north-west coast of Peninsular Malaysia. Natural Hazards, 2012; 63:549-573.

21. Vicente RS, Varum H, Mendes da Silva JAR. Seismic vulnerability assessment of buildings in the old city centre of Coimbra. Pp. 206-213 in Proceedings of the International Conference 250th Anniversary of the 1755 Lisbon Earthquake, Lisbon, 2005.

22. Vicente RS, Parodi S, Lagomarsino S, Varum H, Mendes da Silva JAR. Seismic vulnerability and risk assessment: Case study of the historic city centre of Coimbra, Portugal. Bulletin of Earthquake Engineering, 2011; 9:1067-1096.

23. Ferreira TM, Vicente R, Mendes da Silva JAR, Varum H, Costa A. Seismic vulnerability assessment of historical urban centres: Case study of the old city centre in Seixal, Portugal. Bulletin of Earthquake Engineering, 2013; 11:1753-1773.

24. Santos C, Ferreira TM, Vicente R, Mendes da Silva JAR. Building typologies identification to support risk mitigation at the urban scale: Case study of the old city centre of Seixal, Portugal. Journal of Cultural Heritage, 2013; 14:449-463.

25. Ribeiro J, Silva A, Leitão, P. High resolution tsunami modelling for the evaluation of potential risk areas in Setúbal (Portugal). Natural Hazards and Earth System Sciences, 2011; 11:2371-2380.

26. Freire S, Aubrecht C. Assessing spatio-temporal population exposure to tsunami hazard in the Lisbon metropolitan area. P. 5 in Proceedings of the ISCRAM 2011, 8th International Conference on Information Systems for Crisis Response and Management, Lisbon, Portugal, 2011.

27. Freire S, Aubrecht C, Wegscheider S. Spatio-temporal population distribution and evacuation modeling for improving tsunami risk assessment in the Lisbon metropolitan area. P. 6 in Proceedings of Gi4DM 2011, International Symposium on Geoinformation for Disaster Management, Antalya, Turkey, 2011.

28. Santos A, Tavares AO, Emidio A. Comparative tsunami vulnerability assessment of an urban area: An analysis of Setúbal city, Portugal. Applied Geography, 2014; 55:19-29.

29. Barros JL, Tavares AO, Santos A, Fonte A. Territorial vulnerability assessment supporting risk managing coastal areas due to tsunami impact. Water, 2015; 7: 4971-4998.
30. González-Riancho P, Aliaga B, Hettiarachchi S, González M, Medina R. A contribution to the selection of tsunami human vulnerability indicators: Conclusions from tsunami impacts in Sri Lanka and Thailand (2004), Samoa (2009), Chile (2010) and Japan (2011). Natural Hazards and Earth System Science, 2015; 15: 1493-1514.

31. Mück M, Taubenböck H, Post J, Wegscheider S, Strunz G, Sumaryono S, Ismail FA. Assessing building vulnerability to earthquake and tsunami hazard using remotely sensed data. Natural Hazards, 2013; 68: 97-114.

32. Tarbotton C, Dall'Osso F, Dominey-Howes D, Goff J. The use of empirical vulnerability functions to assess the response of buildings to tsunami impact: Comparative review and summary of best practice. Earth-Science Reviews, 2015; 142: 120134.

33. Kumar TS, Mahendra RS, Nayak S, Radhakrishnan K, Sahu KC. Coastal vulnerability assessment for Orissa State, East coast of India. Journal of Coastal Research, 2010; 523-534.

34. Murthy MR, Usha T, Pari Y, Reddy NT. Tsunami vulnerability assessment of Cuddalore using numerical model and GIS. Marine Geodesy, 2011; 34:16-28.

35. Wood NJ, Jones J, Spielman S, Schmidtlein MC. Community clusters of tsunami vulnerability in the US Pacific Northwest. Proceedings of the National Academy of Sciences, 2015; 112: $5354-5359$.

36. Alexander D. Confronting Catastrophe. UK and New York: Terra and Oxford University Press, 2000.

37. Pendleton E, Barras J, Williams S, Twichell D. Coastal vulnerability assessment of the northern Gulf of Mexico to sea-level rise and coastal change. U.S Geological Survey Report, 2010-1146. Available at: http://pubs.usgs.gov/of/ 2010/1146/pdf/ofr2010-1146.pdf, Accessed October 2014.

38. Cutter S, Boruff B, Shirley W. Social vulnerability to environmental hazards. Social Science Quarterly, 2003; 84:242-261.

39. Schmidtlein M, Deutsch R, Piegorsch W, Cutter S. A sensitivity analysis of the social vulnerability index. Risk Analysis, 2008; 28:1099-1114.

40. Mendes JM. Social vulnerability indexes as planning tools: beyond the preparedness paradigm. Journal of Risk Research, 2009; 12:43-58.

41. Chen W, Susan S, Emrich C, Shi P. Measuring social vulnerability to natural hazards in the Yangtze river delta region, China. International Journal of Disaster Risk Science, 2013; 4:169-181.

42. Santos A, Koshimura S, Imamura F. The 1755 Lisbon tsunami: tsunami source determination and its validation. Journal of Disaster Research, 2009; 4:41-52.

43. Santos A. Tsunami hazard assessment in Portugal by the worst case scenario: The November 1st, 1755 Lisbon Tsunami. PhD Thesis, Tohoku University, 2008.

44. Santos A, Koshimura S. A criterion for tsunami hazard assessment at the local scale, Journal of Geodesy and Geomatics Engineering, 2015; 2:87-96.

45. Santos A, Koshimura S. The 1755 Lisbon tsunami at Vila do Bispo municipality, Portugal, Journal of Disaster Research, 2015; 10(6):1067-1080.

46. Henriques EB. A cidade, destino de turismo. Revista da Faculdade de Letras-Geografia, 2003; XIX:163-172.

47. INE. Censos de Portugal de 2011. Available at: http://www. ine.pt, Accessed August 2014.

48. Almeida A. Dunas de Quiaios, Gândara e Serra da Boa Viagem. Uma abordagem ecológica da paisagem. PhD Thesis, Coimbra University, 1995.

49. Cunha PP, Pinto P, Dinis JL. Evolução da fisiografia e ocupação antrópica na área estuarina do Rio Mondego e região envolvente (Portugal centro-oeste), desde 1947. Territorium, 1997; 4:99-124.

50. Dawson AG, Hindson R, Andrade C, Freitas C, Parish $\mathrm{R}$, Bateman M. Tsunami sedimentation associated with the 
Lisbon earthquake of 1 November AD 1755: Boca do Rio, Algarve, Portugal. Holocene, 1995; 5: 209-215.

51. AT. Autoridade Tributária e Aduaneira. 2014. Available at: http://www.e-financas.gov.pt/SIGIMI/default.jsp, Accessed June, 2014.

52. Bana E, Costa CA, Silva PA, Correia FN. Multicriteria evaluation of flood control measures: The case of Ribeira do Livramento. Water Resources Management, 2004; 18:263283.

53. Bana E, Costa CA Chargas M. An example of how to use MACBETH to build a quantitative value model based on qualitative value judgements. European Journal of Operational Research, 2004; 153:323-331.

54. Barros JL, Tavares AO, Santos A, Emídio A. Os SIG na avaliação da vulnerabilidade estrutural e social associada a tsunamis: aplicação aos concelhos de Vila do Bispo e Figueira da Foz. I Jornadas Lusófonas, CTIG, 14 pp. 11-12 Setembro 2014.

55. Tavares AO, Barros JL, Santos A. Tsunami vulnerability in two coastal areas of Portugal: A multidimensional approach. Pp. 91-103 in Kremers H, Susini A (eds). Risk, Models and Applications, Lecture Notes in Information Sciences. Berlin: CODATA Berlin: Germany, 2015.

56. PORDATA. Base de dados Portugal Contemporâneo, 2014. Available at: http://www.pordata.pt, Accessed August, 2014.

57. GEP. Carta Social, 2014. Available at: http://www.carta social.pt, Accessed August, 2014.
58. Mendes JM, Tavares AO, Freiria S, Cunha L. Vulnerabilidade social aos riscos naturais e tecnológicos em Portugal. Revista Crítica de Ciências Sociais, 2011; 93:95-128.

59. Comrey A, Lee H. A First Course in Factor Analysis. New York: Physiology Press, 2009.

60. Tavares AO, dos Santos PP, Freire P, Fortunato AB, Rilo A, Sá L. Flooding hazard in the Tagus estuarine area: The challenge of scale in vulnerability assessments. Environmental Science \& Policy, 2015; 51:238-255.

61. Santos A, Mendes S, Corte-Real J. Impacts of the storm Hercules in Portugal. Finisterra, 2014; 98: 197-220.

62. Balica SF, Wright NG, van der Meulen F. A flood vulnerability index for coastal cities and its use in assessing climate change impacts. Natural Hazards, 2012; 64: 73-105.

63. Alberico I, Di Fiore V, Iavarone R, Petrosino P, Piemontese L, Tarallo D, Punzo M, Marsella, E. The tsunami vulnerability assessment of urban environments through freely available datasets: The case study of Napoli City (southern Italy). Journal of Marine Science and Engineering; 2015, 3:9811005.

64. Huang J, Liu Y, Ma L, Su F. Methodology for the assessment and classification of regional vulnerability to natural hazards in China: The application of a DEA model. Natural Hazards, 2013; 65:115-134.

65. Wang JF, Li LF. Improving tsunami warning systems with remote sensing and geographical information system input. Risk Analysis, 2008; 2:1653-1668. 